\title{
Changing the Way the United States Measures Income and Poverty: A Progress Report $^{1}$
}

This paper reports the general results of research undertaken by Census Bureau staff. The views expressed are attributable to the authors and do not necessarily reflect the views of the Census Bureau or the U.S. government. The authors would like to acknowledge and thank the following people for their comments and suggestions-Nancy Gordon, Edward Welniak and the coauthors of the other papers cited in this report; they bear no responsibility for any errors that remain.

\section{BACKGROUND - THE OFFICIAL DEFINITION The United States Census Bureau has been compiling income estimates annually since 1947 . These estimates are from the Current Population Survey (CPS), a nationwide random sample of households, whose primary purpose is to collect labor force information monthly. In March of each year (April prior to 1956), data are collected on the household's income for the previous calendar year.}

The official definition of income is not specified in law or regulation. In effect, what is included in income depends on the questions asked. As survey researchers know, the more questions one asks about income by source, the better able respondents are to identify all income. Initially, there were only two questions asked of each adult: ${ }^{2}$ (1) "How much did ... earn in wages and salaries in 1947?" and (2) "How much income from all sources did ... receive in 1947?". In 1949, self-employment income was asked separately and in 1950 farm and nonfarm self-employment income was asked separately. In 1962, the Census Bureau began systematically assigning values to missing income items (based on reported characteristics using the "hot deck" method). In March 1967, the number of income questions was again expanded, from four to eight categories. These additional items dealt with Social Security, interest, dividends, and rent. In 1968, interest, dividends, rents, and royalties were combined into one question and separate questions were added on public assistance and on unemployment and workers' compensation. In 1975, the number of income questions increased from eight to eleven through addition of a question on the Supplemental Security Income program, a question on Aid to Families with Dependent Children and general assistance, and private and government pension income. A major change took place in 1980 - the questionnaire was expanded to identify over 50 sources of income and recording of up to 27 different income amounts, including receipt of numerous noncash benefits, such as food stamps (coupons used as cash for qualified food purchases), and housing assistance. Except for minor wording changes, those questions are still in use today. The survey was converted to a computerassisted interviewing mode in 1994.

The data on income thus cover money income received (exclusive of certain money receipts such as capital gains) before payments for items such as personal income taxes, Social Security payroll taxes, and union dues. Money income does not reflect the fact that some families receive part of their income in the form of noncash benefits, such as food stamps, health benefits, rent-free or subsidized housing, and goods produced and consumed on the farm. In addition, money income does not reflect the fact that noncash benefits are also received by some as fringe benefits, e.g. the use of company cars, and full or partial payments by business for retirement programs, medical insurance, and educational expenses.

Moreover, for many different reasons, there is a tendency in household surveys for respondents to underreport their income. From an analysis of independently derived income estimates, it has been determined that income earned from wages or salaries is much better reported than other sources of income and is nearly equal to independent estimates of aggregate earnings (Coder and Scoon-Rogers, 1996).

Among the least well-reported sources are interest and dividends. The detailed components of money income are presented in the Appendix.

\section{ALTERNATIVE MEASURES OF INCOME}

Because money income is but one measure of economic well-being, the Census Bureau also reports on 14 other definitions of income (the series begins in 1979). While not exhaustive, they do illustrate different perspectives on what could be included.

Definition 1. Money income excluding capital gains before taxes. This is the official definition described above. 
Definition 2. Definition 1 less government cash transfers. Government cash transfers include nonmeans-tested transfers such as Social Security payments, unemployment compensation, and government educational assistance (e.g., Pell Grants), as well as means-tested transfers such as Aid to Families with Dependent Children (AFDC), Temporary Assistance to Needy Families, and Supplemental Security Income (SSI).

Definition 3. Definition 2 plus capital gains. Realized capital gains and losses are simulated as part of the Census Bureau's Federal individual income tax estimation procedure. While the Census Bureau has access to some income information on individual tax returns that can be matched (with substantial time lag) to survey data, actual capital gains or losses or tax liability are not known.

Definition 4. Definition 3 plus imputed health insurance supplements to wage or salary income. Employer-paid health insurance coverage is treated as part of total worker compensation; no other benefits paid for or provided by employers are estimated.

Definition 5. Definition 4 less payroll taxes. Payroll taxes are payments for Social Security old age, survivors, and disability insurance, and for hospital insurance (Medicare).

Definition 6. Definition 5 less Federal income taxes. The effect of the Earned Income Tax Credit, targeted to low-income workers, is shown separately in Definition 7.

Definition 7. Definition 6 plus the Earned Income Tax Credit.

Definition 8. Definition 7 less state income taxes.

Definition 9. Definition 8 plus nonmeans-tested government cash transfers. Nonmeans-tested government cash transfers include Social Security payments, unemployment compensation, workers' compensation, nonmeans-tested veterans' payments, U.S. railroad retirement, Black lung payments, and Pell Grants and other government educational assistance. (Pell Grants are income-tested but are included here because they are very different from the assistance programs included in the means-tested category.)

Definition 10. Definition 9 plus the value of Medicare. Medicare is counted at its fungible value. ${ }^{3}$

Definition 11. Definition 10 plus the value of regular-price school lunches.
Definition 12. Definition 11 plus means-tested government cash transfers. Means-tested government cash transfers include AFDC, SSI, other public assistance programs, and means-tested veterans' payments.

Definition 13. Definition 12 plus the value of Medicaid. Medicaid is counted at its fungible value.

Definition 14. Definition 13 plus the value of other means-tested government noncash transfers. Including food stamps, rent subsidies, and free and reduced-price school lunches.

Definition 15. Definition 14 plus net imputed return on equity in one's own home. This definition includes the estimated annual benefit of converting one's home equity into an annuity, net of property taxes.

Table 12 is a reproduction of a table from U.S. Bureau of the Census (1996a) illustrating the different distributions of income that these definitions imply. ${ }^{4}$ Table 5 (U.S. Bureau of the Census, 1996b) illustrates this effect on poverty estimates.

These alternative definitions illustrate the dilemma faced by official statisticians when presenting income statistics. Different definitions serve different purposes. Money income has its uses - it represents command over the resources available to purchase the necessities of life in the open market, including meeting the obligations of citizenship (taxes). Definition 4 probably comes closest to measuring what resources would be available in the absence of government, except that some benefits paid for or provided by employers are not included and others are mandated by the government, some benefits are not provided by employers because they are provided by the government, and work effort is presumably reduced by the existence of a tax on earnings. Definition 8 is closest to after-tax income. Disposable income tries to take account of the effect of taxes and transfers on the household's command of resources - definition 14 probably comes closest to that approach. Finally, in definition 15 there is an attempt to include the income equivalent value of owning one's own home in that such an asset reduces the need for additional expenditures on shelter.

\section{CONSIDERATIONS IN MEASURING POVERTY}

Formal measurement of poverty in the United States is less than three decades old. Not since the adoption of official poverty thresholds by the Federal government in the late 1960 's has there been such a great interest as now in examining and possibly respecifying the thresholds and the income compared with them. The official poverty thresholds in use today by the U.S. Bureau of the Census to measure poverty have their basis in work by Orshansky 
(1963, 1965). Orshansky started with a set of minimally adequate food budgets calculated for families of various sizes and composition by the U.S. Department of Agriculture for 1961. Based on evidence from the 1955 Household Food Consumption Survey, she determined that expenditures on food represented about one-third of aftertax income for the typical family. This relationship yielded a "multiplier" of three, that is, the minimally adequate food budgets were multiplied by a factor of three to obtain 124 poverty thresholds that differed by family size, number of children, age and sex of head, and farm or nonfarm residence (ad hoc adjustments were made for families of size one and two).

In 1969, the U.S. Bureau of the Budget (now the U.S. Office of Management and Budget - OMB) adopted the Orshansky measure using pre-tax income as the standard government poverty measure, mandating that thresholds be adjusted for inflation using the Consumer Price Index (CPI) published by the U.S. Bureau of Labor Statistics. With only minor modifications since then (mostly reducing the number of categories, now 48), the Orshansky thresholds still form the basis for the official poverty statistics. ${ }^{5}$

When considering the adequacy of the official poverty thresholds, it is critical to realize that one cannot separate the issue of income measurement from poverty definition. When one defines the level of resources needed to be nonpoor, one must also determine which resources are to be counted. Therefore, the discussion below covers both income measurement and poverty definition issues; income measurement is discussed first. ${ }^{6}$

Whatever poverty thresholds are chosen should be the result of a carefully specified process that cannot be changed arbitrarily from year-to-year, and should be capable of being updated at reasonable intervals as the economic circumstances of the society and the behavior of its demographic and economic components change.

\section{A. DEFINING INCOME FOR MEASURING POVERTY}

The key measurement issues are three — valuing and counting noncash income, subtracting taxes, and reducing survey underreporting and nonsampling errors. Also of interest is whether to continue to publish official estimates based on the CPS or switch to a newer survey designed to collect better income information, the Survey of Income and Program Participation (SIPP).

\section{A.1. Noncash income}

The issue of valuing noncash income spans the income distribution. A more comprehensive income measure, such as definition 14 above, would place a value not only on noncash government transfers, such as food stamps, which typically go to low-income families, but also on elements of nonwage compensation (from employer-paid health insurance to company cars) that typically go to earners at all income levels or only at high levels. The noncash income of U.S. families has grown substantially in the past 25 years. In the 1990's, over half of government transfer spending for the poor is in the form of noncash benefits (U.S. Bureau of the Census, 1996a), whereas the only noncash benefit program that predated the 1960's "War on Poverty" was subsidized (public) housing. This growth of benefits to the poor has been paralleled by a growth of nonwage compensation to wage earners, induced in part by tax laws exempting such compensation from income and payroll taxes, and by growth in health benefits for the elderly. By 1996, employer costs for nonwage compensation had grown to over one-quarter ( 28.4 percent) of total compensation costs, up from 19.4 percent in $1966 .^{7}$ Further, nearly two-thirds of households own homes, which provide them with additional noncash income in the form of housing services.

Of key concern to understanding the well-being of U.S. households is the valuation of medical benefits, both the government health programs-Medicare (medical aid to the elderly and severely disabled) and Medicaid (medical aid to a portion of the poor) — and employer-paid health insurance. The valuation of medical benefits is particularly difficult since coverage of high medical expenses for people who are sick does nothing to improve their poverty status (although the benefits clearly make them better off). Even if one imputes the value of an equivalent insurance policy to program participants, these benefits (high in market value due to large medical costs for the fraction who do get sick), and cannot be used by the recipients to meet other needs of daily living. Accordingly, the Census Bureau developed a not-altogether-satisfactory method, termed fungible value (described in footnote 2), to avoid giving too high a value of these benefits to those toward the low end of the income scale. Note that this is not a problem for countries with universal health care systems.

\section{A.2. Disposable income}

Even though Orshansky's original calculations were based on post-tax income, poverty has always been calculated for the official statistics using pre-tax income because of the limited information collected on the CPS. After-tax income is a better measure of the ability to meet the daily necessities of life than is money income. Also important, in calculating disposable income though, is to address the advisability of deducting work expenses for wage earners such as child care, uniforms, and transportation costs.

\section{A.3. $\underline{\text { Other issues }}$}

As noted earlier, research matching household survey responses to Federal income tax returns and comparing them with national income accounts has revealed substantial areas where the level and receipt of certain 
income sources is underreported. Attempts to reduce underreporting were made by revising the language used in the CPS questionnaire (and using a shorter reference period) when the SIPP was launched. This was only partially successful, and response errors remain.

While current procedures of the Census Bureau reweight the data for full interview nonresponse and impute appropriate income responses for individual unanswered questions (item nonresponse), these corrections are insufficient to fully resolve the problem. Procedures to enhance the data through microsimulation or other means are being investigated, along with continued improvement in imputation for nonresponse.

In most societies, "underground," "nonmarket," or "black market" income from legal or illegal activities is typically poorly reported by household respondents to government surveys (or not even collected) and consequently is substantially omitted from official income statistics. This income ranges from barter transactions to home production (e.g., home gardens) to illegal income. Researchers are a long way from measuring this activity accurately, however, so including this income in official statistics would be quite difficult.

It has been suggested that consumption is a better measure of well-being than income (see Cutler and Katz, 1991, and Slesnick, 1993). If a family can maintain its consumption through judicious use of assets when income falls, is it truly poor? Unfortunately, it is difficult to collect accurate annual data on consumption or even expenditures. Further, consumption reflects choices on how to allocate resources, rather than need. Nevertheless, fuller investigation of a consumption-based measure would be useful.

A final issue of income measurement is the choice of surveys to use. As mentioned briefly above, the SIPP questionnaire design, as crafted to reduce income underreporting, does succeed for almost all income sources. ${ }^{8}$ Yet, when compared with the CPS, it has historically had several drawbacks - a smaller sample size (one-third as large) and necessarily slower data release because of its much greater complexity. These defects are compensated for by the SIPP having greater income detail, both in number of sources and in time segments (by having monthly as opposed to the CPS's annual statistics,) and lower underreporting. The new version of the SIPP, as implemented in 1996, increased the sample size substantially (to 36,700 households) and oversampled lowincome households. National estimates from the SIPP will then be comparable to or better than (in terms of sampling error) those from the CPS (reduced to 48,000 households but inefficient for national estimates because it uses a statebased design). One drawback for obtaining a consistent time series of annual national income or poverty estimates from the SIPP, though, will be sample attrition and time-in- sample bias as current plans call for only one SIPP panel to be in the field during any one four-year period. The CPS sample is constantly refreshed by new households.

While the timeliness issue may never be resolved fully in SIPP's favor, the SIPP can provide a preliminary estimate on much the same schedule as the CPS. Still, it is desirable to view the surveys complementarily. If modeling using administrative records can correct underreporting errors in both surveys, they would then give the same aggregate statistics. The CPS could be used for a quick snapshot, consistent with data collected since 1947 (the SIPP began in 1983), while the SIPP would be used for more detailed estimates, for subannual and multiyear estimates, and for understanding other dimensions of poverty (assets, disability, gross flows, and other dynamic aspects). ${ }^{9}$

\section{B. SETTING THRESHOLDS TO DEFINE POVERTY}

With an absolute measure of poverty, there are key decisions to be made about determining the appropriate level for poverty thresholds. The key research issues addressed here are minimal consumption levels for specific commodities, ways of correcting for differences in family size and composition, and ways of correcting for cost-ofliving differences across time and among areas.

\section{B.1. Minimal consumption standards}

Minimal consumption standards for all necessary commodities could in theory be established, perhaps by an expert panel, but doing so would raise difficult ethical issues about which commodities to include (e.g., is a telephone a necessity?). One alternative is to define minimal consumption standards for a limited number of necessities (e.g. food, clothing, shelter) and obtain a poverty threshold by using a multiplier to account for necessities not measured. ${ }^{10}$

\section{B.2. Equivalence scales}

The relationship embodied in the current U.S. poverty thresholds among families of different sizes (termed the equivalence scale) is supposed to represent the different relative costs of supporting those families at a minimally adequate levels. In fact, the relationship is based solely on the relative food costs as they existed in 1961 and include some unfortunate anomalies (see Ruggles, 1990, pp. 6468). While it is possible to develop minimal budgets for every type and size of family separately and thus eliminate the need for equivalence scales entirely, in practice it is difficult to do so. No one scale now exists that is generally accepted. Issues in developing equivalence scales include which distinctions in family circumstances (e.g. owner/ renter) should lead to different thresholds, how resources are shared within the family or household, and whether a more useful basis for determining poverty is the household (those living in one housing unit) rather than the family 
(those in one household related by blood or marriage). See Betson (1996) for a further discussion of these issues.

\section{B.3. Cost-of-living differences}

In as large and diverse a country as the U.S., there are significant differences in the cost of living among localities. Unfortunately, there are no currently available data upon which to estimate interarea price differences reliably. (See Kokoski et al., 1992, and Moulton, 1992, for some work in this area.)

A related price issue is how to adjust for inflation. The U.S. poverty thresholds now use the CPI to adjust thresholds over time. If the measurement of minimal consumption is used as the basis for new thresholds, presumably this should be the basis every year, with components, prices, and multipliers reestimated as often. Clearly this is not practical. A reasonable compromise might be to respecify and reestimate the minimal consumption bundle at prespecified intervals as market baskets become outdated, say every ten years, and use the CPI for interim adjustments. The market basket used for the CPI itself is typically reviewed and respecified once every ten years or so. ${ }^{11}$

\section{THE COMMITTEE ON NATIONAL STATISTICS REPORT}

The National Academy of Sciences' Committee on National Statistics (CNStat) released a report in May 1995 entitled Measuring Poverty: A New Approach (Citro and Michael, 1995). In that report, the committee recommended that the Federal government redefine the way it measures poverty. OMB has requested that experts from the Census Bureau and other agencies examine technical methods for doing so.

The key changes they recommend are threefold: change the income measure, change the poverty thresholds, and change the survey used. To change the income measure from the current money income definition, they propose to add noncash benefits, subtract taxes, subtract work expenses, subtract child care expenses, subtract child support paid, and subtract medical out-of-pocket expenses (MOOP). The poverty thresholds are to be based on food, clothing, shelter, and "a little bit more" (75-83\% of median expenditures on these items multiplied by $1.15-1.25$ ), a new equivalence scale, an allowance for geographic variation, and are to be updated annually based on growth in median expenditures. Finally, the panel recommended that the government use the SIPP instead of the March CPS to collect the basic income and poverty-related data.

Among the technical issues to be resolved before implementing such a new measure are the following:

1. Reestimating the valuation methodologies for government noncash transfer programs including school lunches, food stamps, and housing benefits; developing new estimation methodologies for additional programs and possibly developing a new methodology for valuing Medicare and Medicaid (depending on whether the subtraction of MOOP is adopted or not);

2. Completing development of a tax simulation model for SIPP;

3. Developing a methodology for estimating MOOP (e.g. a statistical match of the National Medical Expenditures Survey to SIPP) or reestimation of employer contributions to health insurance using more recent data;

4. Estimating and imputing work and child care expenses;

5. Redesigning the SIPP sampling scheme to maximize reliability of a time series of cross-section estimates while maintaining some longitudinal estimation capabilities, taking account of the need for state-level estimates, and minimizing the attrition bias;

6. Reviewing the Consumer Expenditure Survey to improve its effectiveness for its new dual role (defining the market basket for the Consumer Price Index and the poverty thresholds) and possibly preparing for consumption-based rather than income-based poverty estimates in the future;

7. Creating a time series of poverty estimates from the SIPP and developing methods to impute additional variables to the CPS to develop comparable time-series data for that survey;

8. Doing substantial further work on income underreporting and imputation models;

9. Adding child support and alimony paid questions to CPS; and

10. Developing and adding "medical care risk" and possibly medical expenditures questions to SIPP to supplement the poverty measure if medical care costs and benefits are excluded from the measure.

Even if these technical issues can be resolved expeditiously, there are still policy issues that must be debated and resolved before a new measure is adopted. These include:

1. Including or excluding medical costs and benefits. On the one hand, the CNStat recommended excluding MOOP, employer contributions to health insurance, and benefits from medical transfer programs from income. On the other hand, adopting as official the current (experimental) practice of including them would require 
improving the current method for valuing medical transfer program benefits, measuring medical needs more accurately, and updating the methodology for imputing employer contributions to health insurance.

\section{Basing thresholds on a pre-specified fraction of} median expenditures. How might the public and Congress react to a new poverty threshold that showed millions more poor persons than the current measure? Are we confident enough about the quality of (i.e. lack of biases in) the Consumer Expenditure Survey data to use it as the arbiter of the poverty level? It may be that the likely acceptance of any new definition would be enhanced if the new index were "chained" to the old by matching the overall poverty rate obtained (but allowing the distribution to vary).

3. Developing geographical cost-of-living variations. It is clear that the cost of living differs substantially from place to place, and different choices of methodology to reflect this fact would have different implications. If geographic variation is to be incorporated, some method for periodically updating the thresholds for relative price changes among areas would also need to be established.

4. Annual inflation updating. The panel proposed using the rate of growth in expenditures to index the thresholds. This is an attempt to introduce some deliberate "relativity" into the measure and would have quite different ramifications from using the Consumer Price Index.

5. Choosing the equivalence scale. Choice of the scale would inevitably alter the distribution of the poor.

6. Underreporting. If the technical issues about how to do so are resolved, should the income statistics from the survey be adjusted for underreporting based on administrative data and modeling?

7. Review and Revision. Should any new definition include a regular cycle of review and revision based on pre-specified criteria (CNStat recommended once a decade)?

Open debate of these issues seems the most likely way to resolve them, potentially leading to a new way of measuring poverty that OMB would approve and that other policy makers would accept as an improved methodology for measuring poverty in the United States.

\section{CENSUS BUREAU POVERTY REDEFINITION RESEARCH}

In order to provide a basis on which some of these issues can be resolved, the Census Bureau and other U.S. government agencies have begun research studies.
D.1. Census Bureau-Bureau of Labor Statistics Study The CNStat report on redefining poverty contained sweeping recommendations for changing the way poverty is defined in the U.S. Recent joint research by the Bureau of the Census and the Bureau of Labor Statistics (BLS) (Garner et al., 1997) examined two of these issues changing the income definition and modifying the poverty thresholds.

In formulating poverty thresholds, BLS researchers started by implementing the basic recommendations from the CNStat report. Some of the CNStat panel recommendations regarding thresholds were given as ranges. Thus, some simplifying assumptions were made. First, the panel recommended a range of thresholds, with a lower bound based on 78 percent of median expenditures for food, clothing, and shelter and a multiplier of 1.15 to account for other needs. The upper bound was based on 83 percent of the median and a multiplier of 1.25. In the Garner et al. paper the midpoint of this range was used. The other simplifying assumption was for the equivalence scale (the relationship between thresholds for different family sizes). The panel recommended a range of economy scale factors of 0.65 to 0.75 and again they choose the midpoint - 0.70. Thresholds were computed for the years 1990 through 1995.

On the resource side, the panel's recommendations were followed to the extent possible. The only recommendation not followed (because of a lack of data) was their recommendation to subtract child support paid from income when computing a poverty resource measure. Though the panel recommended changing the official source of poverty statistics in the U.S. from the CPS to the SIPP, the initial work was based on the CPS. At this time, the CPS is the only survey with a working tax simulation model and in-kind benefit valuation procedures, both necessary ingredients for producing a resource measure based on the panel's recommendations.

The report found that the threshold computation methods as recommended by the panel result in relatively stable thresholds over time (at least over the 1990-1995 period measured in this study), and the resulting poverty rates based on applying the panel's basic resource definition to these thresholds also showed relatively stable results. In fact, though the panel's recommendations result in significantly higher poverty rates than the U.S. official estimates, the trends based on the official estimates and the panel's recommended method show very similar trends over the 1990-1995 period (see Figure 1). Differences across subgroups were also found to be stable over time. However, the key change under the proposed definition of poverty is in the composition of the poverty population. Consistent with the panel's findings, poverty rates under the recommended poverty measure are significantly higher among groups with relatively low official poverty rates (for 
example, Whites or those living in married-couple families). Groups with relatively high poverty rates, on the other hand, did not tend to have very different poverty rates under the revised measure. Thus, an effect of moving to the recommended poverty measure would be to narrow the gaps that now exist in the U. S. between high- and lowpoverty groups (married-couple and single-parent families, Whites and Blacks, etc.). Put another way, under the revised measure, the poverty population looks more like the total population in terms of demographic and socioeconomic characteristics. (See Table 1 and Figures 24.)

Other, slightly different poverty thresholds were also examined in the Census-BLS study. One modification, which was suggested by the panel, was to define shelter costs by their rental equivalent value. This technique resulted in higher poverty thresholds (and higher poverty rates), and appeared to have some effect on the composition of the poverty population (further narrowing the gaps, for example, between high-and low-poverty groups). Another set of thresholds was based on alternative multipliers that were computed more precisely than those used in the Panel's report. This modification resulted in little change in the composition of the poverty population.

\section{D.2. Other Census Bureau Poverty Research}

The panel recommended changing the source of official U.S. poverty estimates from the March CPS to the SIPP. As noted earlier, the SIPP is a longitudinal survey with: 1) a more detailed set of questions than the CPS, 2) a shorter reference period (4 months versus 12 months for the CPS), and 3 ) increased flexibility sufficient to add the questions required to measure poverty based on the broadened resource definition recommended by the panel. Questions have already been added to SIPP to collect some of this additional information, and a sample design change, in order to make SIPP a better cross-sectional survey (a requirement for measuring annual poverty changes) has been proposed, though not yet adopted.

The Census Bureau has also examined the panel's recommendations on work-related and child- care expenses (the panel recommended subtracting these costs from income when computing the poverty resource measure and has suggested alternative methods for imputing such costs). This research showed that using a definition of resources that excludes child care and other work-related expenses has a significant effect on poverty rates. In both CPS and SIPP-based analyses, the effect of using a resource definition that excluded these expenses was to raise children's poverty rates by about 3 percentage points. (See Short et al., 1996.)

Another area of research at the Census Bureau is on the housing subsidy valuation method. The value of public or subsidized housing is included in the recommended poverty measure, and the current Census Bureau method for imputing such subsidies (on the CPS) is badly outdated. Current methods are being reviewed, and ways to implement this imputation on SIPP are being explored. A paper is planned for presentation in August (Eller and Naifeh, forthcoming).

The one major element of the panel's recommended resource measure not included in the Census Bureau-BLS study was the subtraction of child support paid, since this information was not available in the CPS. Data from SIPP indicate that the inclusion of such payments would increase the poverty rate by 0.3 to 0.5 . Questions were added to the April 1996 CPS Supplement on child support to examine the feasibility of capturing this information on a regular basis on the March CPS. Data on child support paid are regularly collected on SIPP.

As already noted, the treatment of medical benefits and expenditures in defining poverty is a difficult one. Staff are currently examining the treatment of medical out-of-pocket expenditures in the definition of poverty (see Doyle, forthcoming(a)). To come up with a definition of income that excludes these expenditures, our current thinking is that statistically matching SIPP to another Federal government survey that includes detailed information about these expenditures (the Medical Expenditure Panel Survey) holds the most promise. In addition, staff are working on a proposed medical care risk index to complement the new poverty measure (to address another recommendation of the panel). (See Doyle, forthcoming(b).)

Since the panel recommended an after-tax income definition for its poverty measure, one problem with transferring the official poverty measure from the CPS to SIPP is the lack of a working tax simulation model based on the SIPP (since the early 1980's, the CPS has employed a model to estimates taxes). The Census Bureau, along with several other Federal agencies, supported the development of a SIPP-based tax model, and we are now in the process of exploring how to best incorporate this model into the Census Bureau's processing system.

Equivalence scales are an important issue in the formulation of poverty thresholds. Betson (1996) provides compelling evidence that the choice of equivalence scales has a significant effect on the composition of the poverty population. He also pointed to the need for continued research in this area.

In another paper, Betson (1995) examined the issue of home ownership and whether the flow of housing services from owner-occupied homes should be taken into account when defining poverty status. He found that counting the value of housing services would change the distribution of the poor, primarily by counting fewer of the elderly as poor. 
Table 5. Poverty Rates:

Official and Experimental by Race, Hispanic Origin, Family Type and Age: 1992

\begin{tabular}{|l|l|l|l|}
\hline & Official & Experimental & Percent Difference \\
\hline All Persons & 14.8 & 19.9 & 34.5 \\
\hline White & & & \\
\hline Black & 11.9 & 17.1 & 43.7 \\
\hline $\begin{array}{l}\text { Hispanic Origin } \\
\text { Of any race) }\end{array}$ & 33.4 & 37.1 & 11.1 \\
\hline & 29.6 & 41.5 & 40.2 \\
\hline Married Couple & & & \\
\hline Female Household & 7.7 & 13.7 & 77.9 \\
\hline & 39.0 & 42.8 & 9.7 \\
\hline Under 18 Years Old & 22.4 & & 21.0 \\
\hline $18-64$ Years Old & 11.9 & 27.1 & 37.0 \\
\hline 65 Years Old and Over & 12.9 & 16.3 & 74.4 \\
\hline
\end{tabular}

\section{E. CONCLUDING REMARKS}

We believe that prospects for developing a consensus around a new measure of poverty in the United States are the highest since the current measure was adopted in the 1960's. Converting the measure to the SIPP is not costless, though, and budgetary pressures may cause a delay even if a broad methodological consensus is reached.

Furthermore, delicate negotiations over broad policy issues must ensue before any change is made.

Readers are welcome to follow further developments as they happen. Visit the special poverty measurement web site at http://www.census.gov/hhes/www/povmeas.html.

\section{APPENDIX: DEFINITION OF MONEY INCOME}

The current official U.S. definition of income is based on questions which are asked of each person in the CPS sample household 15 years old and over. ${ }^{12}$ These questions cover the amount of money income received in the preceding calendar year from each of the following sources.
Earnings from longest job (or self-employment) and other employment earnings can be classified into three types: (1) Money wage or salary income is the total received for work performed as an employee during the income year. This category includes wages, salary, Armed Forces pay, commissions, tips, piece-rate payments, and cash bonuses earned, before deductions were made for items such as taxes, bonds, pensions, and union dues; (2) Net income from nonfarm self-employment is the net money income (gross receipts minus expenses) from one's own business, professional enterprise, or partnership. Gross receipts include the value of all goods sold and services rendered. Expenses include items such as costs of goods purchased, rent, heat, light, power, depreciation charges, wages and salaries paid, business taxes (not personal income taxes); ${ }^{13}$ and (3) Net income from farm self-employment is the net money income (gross receipts minus operating expenses) from the operation of a farm by a person on their own account, as an owner, renter, or sharecropper. Gross receipts include the value of all products sold, payments from government farm programs, money received from the rental of farm equipment to others, rent received from farm property if payment is made based on a percent of crops produced and incidental receipts from the sale of items 


\section{Figure 1. Poverty Rates: Official and Experimental: 1990-1995}

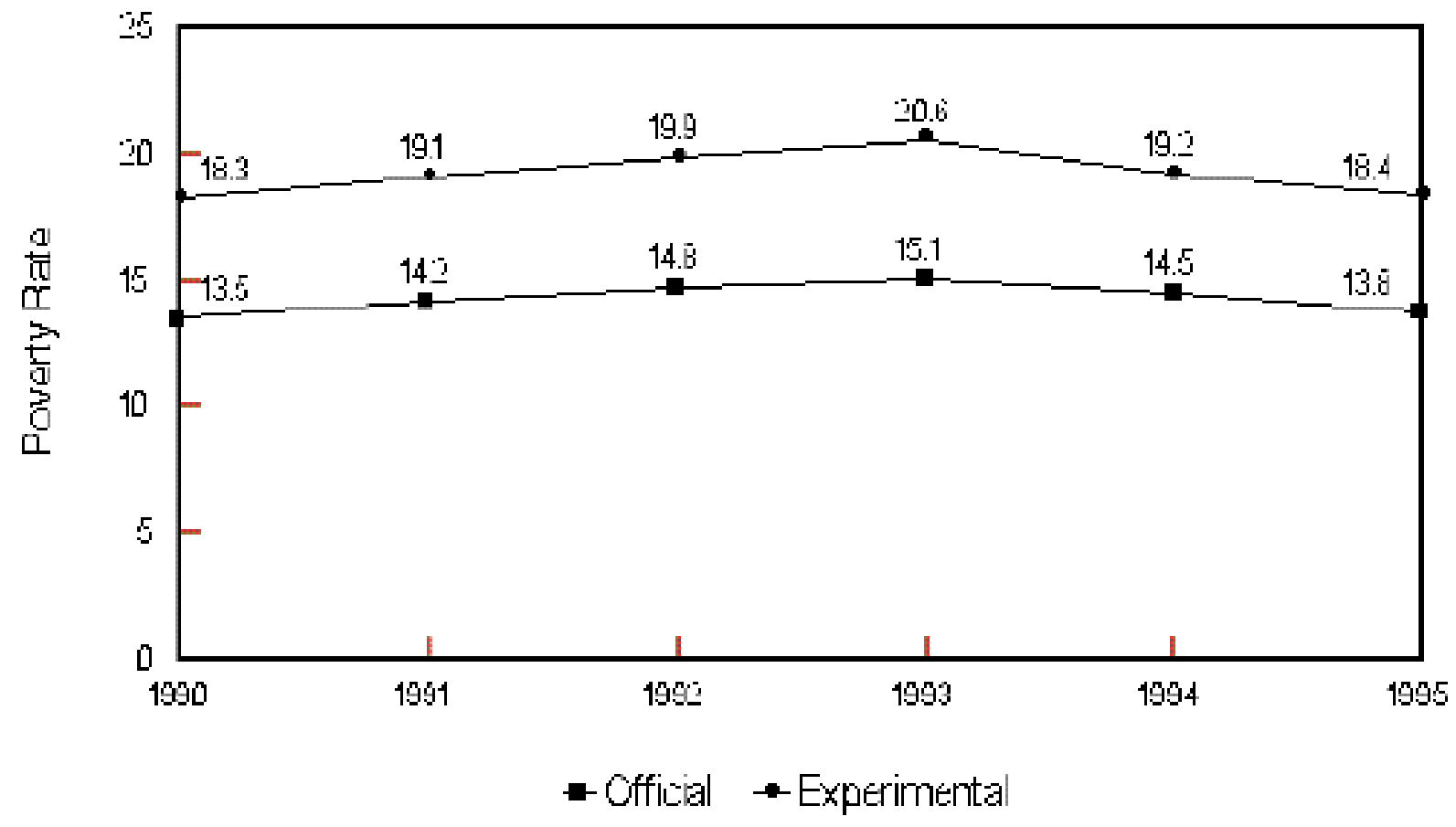

such as wood, sand, and gravel. Operating expenses include items such as the cost of feed, fertilizer, seed, and other farming supplies; cash wages paid to farmhands; depreciation charges; cash rent; interest on farm mortgages; farm building repairs; and farm taxes (not state and Federal personal income taxes). The value of fuel, food, or other farm products used for family living is not included as part of net income. ${ }^{14}$

Unemployment compensation includes payments received from government unemployment agencies or private companies during periods of unemployment and any strike benefits received from union funds.

Workers' compensation includes payments received periodically from public or private insurance companies for injuries received at work.

Social Security includes Social Security (old age) pensions and survivors' benefits and permanent disability insurance payments made by the Social Security Administration prior to deductions for medical insurance. Medicare reimbursements for health services are not included.

Supplemental Security Income includes payments made by
Figure 2. Composition of the Poverty Population, Official and Experimental, by Race: 1992
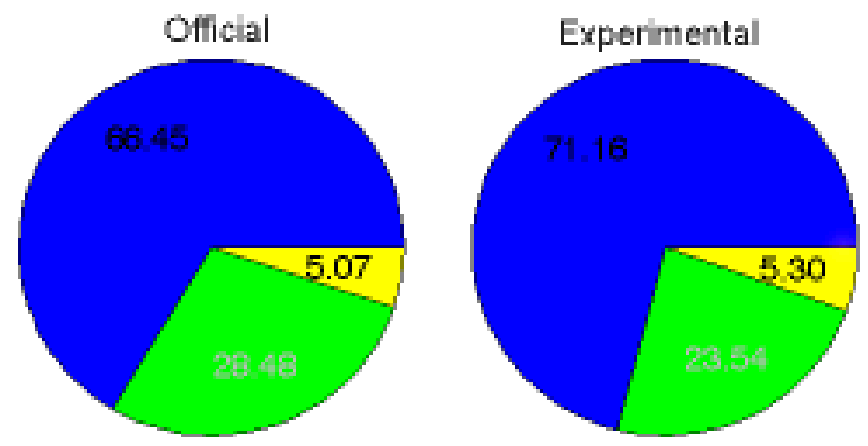

White $\square$ elack $\square$ othor 
Figure 3. Composition of the Poverty Population, Official and Experimental, by Family Type: 1992

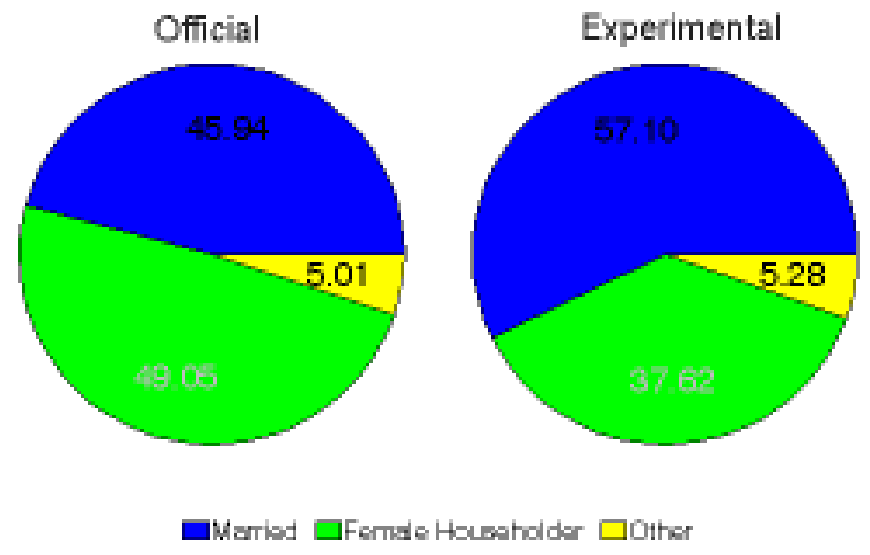

Federal, state, and local welfare agencies to low income persons who are 65 years old or over, blind, or disabled.

Public assistance or welfare payments include public assistance payments made to low-income persons, such as Aid to Families With Dependent Children, Temporary Assistance for Needy Families, and general assistance.

Veterans' payments include payments made periodically by the Department of Veterans Affairs to disabled members of the Armed Forces or to survivors of deceased veterans for education and on-the-job training, and means-tested assistance to veterans.

Survivor benefits include payments from survivors' or widows' pensions, estates, trusts, annuities, or any other types of survivor benefits. Payments can be reported from ten different sources: private companies or unions; Federal government (Civil Service); military; state or local governments; railroad retirement; workers' compensation; "Black lung" (miners') payments; estates and trusts; annuities or paid-up insurance policies; and other survivor payments.

Disability benefits include payments received as a result of a health problem or disability other than those from Social Security. Payments can be reported from ten sources: workers' compensation; companies or unions; Federal government (Civil Service); military; state or local governments; railroad retirement; accident or disability insurance; Black lung payments; state temporary sickness; or other disability payments.

Pension or retirement income includes payments reported from eight sources: companies or unions; Federal government (Civil Service); military; state or local governments; railroad retirement; annuities or paid-up insurance policies; withdrawals from special (tax-favored) retirement accounts such as Individual Retirement Account (IRA's); or other retirement income.

Interest income includes payments received (or credited to bank accounts), from bonds, treasury notes, IRA's, certificates of deposit, interest-bearing savings and checking accounts, and all other investments that pay interest.

Dividends include income received from stock holdings and mutual fund shares. Capital gains from the sale of stock holdings are not included as income.

Rents, royalties, and estates and trusts include the net income from the rental of a house, store, or other property, receipts from boarders or lodgers, net royalty income, and periodic payments from estate or trust funds.

Educational assistance includes Pell Grants; other government educational assistance; any scholarships or grants; or financial assistance from employers, friends, or relatives not residing in the student's household.

Child support includes all periodic payments made by parents for the support of children, even if these payments are made through a state or local government office. ${ }^{15}$

Alimony includes all periodic payments to ex-spouses. One-time property settlements are not included.
Figure 4, Composition of the Poverty Population, Official and Experimental, by Age: 1992
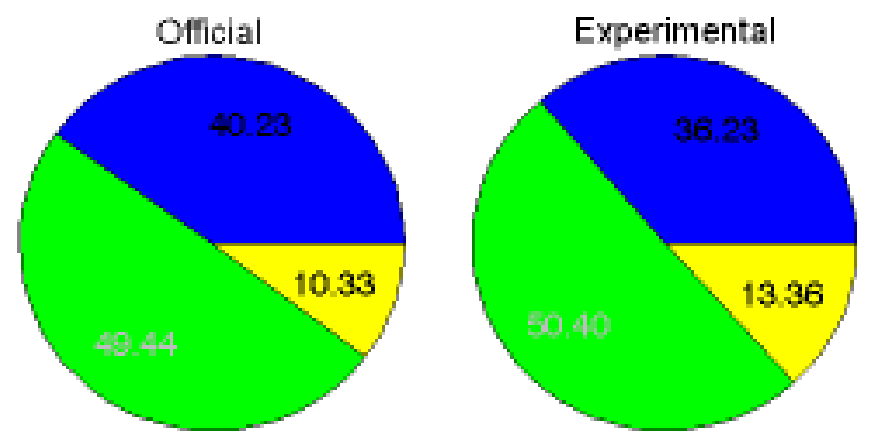

Children (under 19 years) 口Age $18-64$ yous $\square$ Edarly (over 84 years) 
Financial assistance from outside of the household includes periodic payments from nonhousehold members. Gifts or sporadic assistance is not included.

Other income includes all other regularly received payments that are not included elsewhere on the questionnaire. Some examples are state programs such as foster child payments, military family allotments, and income received from foreign government pensions.

Receipts not counted as income include capital gains received (or losses incurred) from the sale of property, including stocks, bonds, a house, or a car (unless the person was engaged in the business of selling such property, in which case the net proceeds would be counted as income from self-employment); withdrawals of bank deposits; money borrowed; tax refunds; gifts; and lump-sum inheritances or insurance payments.

\section{REFERENCES}

Betson, David M. 1996. "“Is Everything Relative?' The Role of Equivalence Scales in Poverty Measurement." University of Notre Dame. March.

Betson, David. 1995. "Effect of Home Ownership on Poverty Measurement." Unpublished paper. November.

Citro, Constance F. and Graham Kalton (eds.). 1993. The Future of the Survey of Income and Program Participation. Washington, DC: National Academy Press.

Citro, Constance F. and Robert T. Michael (eds.). 1995. Measuring Poverty: A

New Approach. Washington, DC: National Academy Press.

Coder, John and Lydia Scoon-Rogers. 1996. "Evaluating the Quality of Income Data Collected in the Annual Supplement to the March Current Population Survey and the Survey of Income and Program Participation." Working Paper. U.S. Bureau of the Census. July.

Cutler, David M. and Lawrence F. Katz. 1991.

"Macroeconomic Performance and the Disadvantaged." Brookings Papers on Economic Activity No. 2, pp. 1-74.

Doyle, Pat. Forthcoming (a). "How Can We Deduct Something We Do Not Collect? The Case of Out-ofPocket Medical Expenditures." U.S. Bureau of the Census.

Doyle, Pat. Forthcoming (b). "Who's at Risk? Designing a Medical Care Risk Index." U.S. Bureau of the Census.

Eller, T.J. and Mary Naifeh. Forthcoming. "Housing Subsidies: Effect of Estimates on Poverty." U.S. Bureau of the Census.
Fisher, Gordon M. 1992. "The Development and History of the Poverty Thresholds." Social Security Bulletin vol. 55 No. 4 (Winter), pp. 3-14.

Garner, Thesia I., Geoffrey Paulin, Stephanie Shipp, Kathleen Short, Charles Nelson. 1997. "Experimental Poverty Measurement for the 1990's." Prepared for the Allied Social Science Meetings, session sponsored by the Society of Government Economists, January 1997; and the SGE Session: Measures of Well-Being From the Consumer Expenditures Survey, January 1997.

Kokoski, Mary, Patrick Cardiff, and Brent Moulton. 1992. "Interarea Price Indices for Consumer Goods and Services: An Hedonic Approach Using CPI Data." U.S. Bureau of Labor Statistics, January.

Moulton, Brent R. 1992. "Interarea Indexes of the Cost of Shelter Using Hedonic Quality Adjustment Techniques." U.S. Bureau of Labor Statistics, October.

Orshansky, Mollie. 1963. "Children of the Poor." Social Security Bulletin v. 26 (July), pp. 3-13.

Orshansky, Mollie. 1965. "Counting the Poor." $\underline{\text { Social }}$ Security Bulletin v. 28 (January), pp. 3-29.

Ruggles, Patricia. 1990. Drawing the Line. Washington, D.C.: Urban Institute Press.

Short, Kathleen, Martina Shea, and T.J. Eller. 1996. "Work-Related Expenditures in a New Measure of Poverty." Prepared for the 1996 Meetings of the American Statistical Association.

Slesnick, Daniel T. 1992. "Gaining Ground: Poverty in the Postwar United States.” Journal of Political Economy Vol. 101 No. 1 (February), pp. 1-38.

U.S. Bureau of the Census, Money Income in the United States: 1995, Current Population Reports P60-193, Washington, DC: U.S. Government Printing Office, September 1996[a].

U.S. Bureau of the Census, Poverty in the United States: 1995, Current Population Reports P60-194, Washington, DC: US Government Printing Office, September 1996[b].

Watts, Harold W. 1993. "A Review of Alternative Budget-Based Expenditure Norms." Prepared for the Panel on Poverty Measurement and Family Assistance of the Committee on National Statistics, revised (May).

Welniak, Edward J., Jr. 1990. "Effects of the March Current Population Survey's New Processing System on Estimates of Income and Poverty." Prepared for American Statistical Association annual meeting, August. 
VALUATION OF NONCASH BENEFITS

Table 12. Income Distribution Measures by Definition of Income: 1995

(Numbers in thousands. Households as of March of the following year. For meaning of symbols, see text)

\begin{tabular}{|c|c|c|c|c|c|c|c|c|c|}
\hline \multirow{4}{*}{ Characteristic } & \multicolumn{3}{|c|}{ Money income- } & \multicolumn{3}{|c|}{ Before taxes } & \multicolumn{3}{|c|}{ After taxes } \\
\hline & \multirow[b]{2}{*}{$\begin{array}{r}\text { Excluding } \\
\text { capital } \\
\text { gains } \\
\text { (current } \\
\text { official } \\
\text { measure) }\end{array}$} & \multicolumn{2}{|c|}{$\begin{array}{l}\text { Definition } 1 \text { less taxes } \\
\text { plus capital gains (losses) }\end{array}$} & \multicolumn{2}{|c|}{ Money income- } & \multirow{2}{*}{$\begin{array}{r}\text { Definition } 3 \\
\text { plus } \\
\text { health } \\
\text { insurance } \\
\text { supplements } \\
\text { to wage or } \\
\text { salary } \\
\text { income }\end{array}$} & \multirow[b]{2}{*}{$\begin{array}{r}\text { Definition } 4 \\
\text { less } \\
\text { Social } \\
\text { Security } \\
\text { payroll } \\
\text { taxes }\end{array}$} & \multirow[b]{2}{*}{$\begin{array}{r}\text { Definition } 5 \\
\text { less } \\
\text { Federal } \\
\text { income } \\
\text { taxes }\end{array}$} & \multirow[b]{2}{*}{$\begin{array}{r}\text { Definition } 6 \\
\text { plus } \\
\text { Earned } \\
\text { Income } \\
\text { Tax } \\
\text { Credit }\end{array}$} \\
\hline & & $\begin{array}{r}\text { Without } \\
\text { EITC }\end{array}$ & With EITC & $\begin{array}{r}\text { Definition } 1 \\
\text { less } \\
\text { government } \\
\text { transfers }\end{array}$ & $\begin{array}{r}\text { Definition } 2 \\
\text { plus } \\
\text { capital } \\
\text { gains } \\
\text { (losses) }\end{array}$ & & & & \\
\hline & 1 & $1 \mathrm{a}$ & $1 b$ & 2 & 3 & 4 & 5 & 6 & 7 \\
\hline \multicolumn{10}{|l|}{ ALL HOUSEHOLDS } \\
\hline $\begin{array}{l}\text { Total } \ldots \ldots \ldots \ldots \ldots \ldots \ldots \ldots \ldots \ldots \ldots \ldots \\
\text { Recipiency Status }\end{array}$ & 99627 & 99627 & 99627 & 99627 & 99627 & 99627 & 99627 & 99627 & 99627 \\
\hline 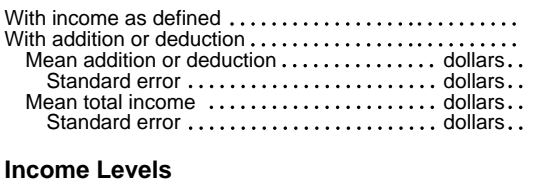 & 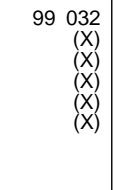 & $\begin{array}{rr}99 & 032 \\
& (X) \\
& (X) \\
& (X) \\
& (X) \\
& (X)\end{array}$ & $\begin{array}{rr}99 & 032 \\
(X) \\
\\
\\
(X) \\
(X) \\
(X) \\
\\
(X) \\
\\
(X)\end{array}$ & $\begin{array}{rr}93 & 004 \\
42 & 392 \\
8 & 879 \\
& 51 \\
23 & 715 \\
& 269\end{array}$ & $\begin{array}{rr}93 & 009 \\
15 & 918 \\
8 & 512 \\
& 308 \\
85 & 353 \\
1 & 309\end{array}$ & $\begin{array}{rr}93 & 009 \\
54 & 312 \\
3 & 897 \\
& 14 \\
64 & 598 \\
& 419\end{array}$ & $\begin{array}{rr}93 & 009 \\
75 & 096 \\
3 & 193 \\
& 13 \\
51 & 682 \\
& 343\end{array}$ & $\begin{array}{rr}93 & 014 \\
73 & 158 \\
7 & 719 \\
99 \\
97 \\
47 & 964 \\
& 252\end{array}$ & $\begin{array}{rr}93 & 014 \\
14 & 860 \\
1 & 250 \\
& 12 \\
20 \quad 696 \\
& 232\end{array}$ \\
\hline 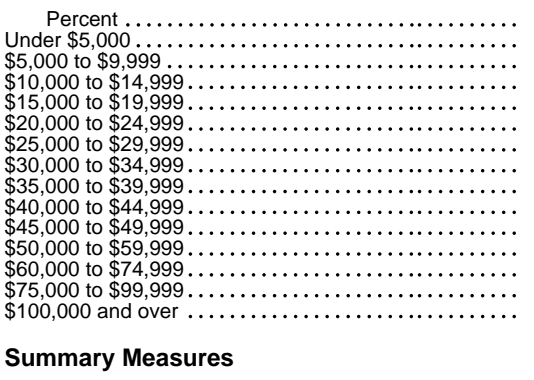 & $\begin{array}{r}100.0 \\
3.7 \\
8.6 \\
8.7 \\
8.3 \\
7.6 \\
7.4 \\
6.8 \\
6.3 \\
5.6 \\
5.0 \\
8.3 \\
8.8 \\
7.7 \\
7.1\end{array}$ & $\begin{array}{r}100.0 \\
3.9 \\
9.3 \\
10.1 \\
9.9 \\
9.4 \\
9.0 \\
7.9 \\
7.2 \\
6.2 \\
4.8 \\
8.0 \\
6.7 \\
4.3 \\
3.4\end{array}$ & $\begin{array}{r}100.0 \\
3.7 \\
8.8 \\
9.6 \\
10.4 \\
9.7 \\
9.1 \\
8.0 \\
7.3 \\
6.2 \\
4.8 \\
8.1 \\
6.7 \\
4.3 \\
3.4\end{array}$ & $\begin{array}{r}100.0 \\
16.5 \\
6.4 \\
6.5 \\
6.5 \\
6.5 \\
6.2 \\
6.0 \\
5.6 \\
5.1 \\
4.5 \\
7.8 \\
8.2 \\
7.3 \\
6.8\end{array}$ & $\begin{array}{r}100.0 \\
16.5 \\
6.3 \\
6.4 \\
6.5 \\
6.6 \\
6.2 \\
6.1 \\
5.5 \\
5.1 \\
4.4 \\
7.7 \\
8.2 \\
7.4 \\
7.1\end{array}$ & $\begin{array}{r}100.0 \\
16.4 \\
6.1 \\
6.0 \\
6.1 \\
6.1 \\
5.9 \\
5.8 \\
5.3 \\
4.9 \\
4.4 \\
8.0 \\
8.6 \\
8.3 \\
8.1\end{array}$ & $\begin{array}{r}100.0 \\
16.7 \\
6.5 \\
6.5 \\
6.5 \\
6.4 \\
6.3 \\
5.9 \\
5.5 \\
5.0 \\
4.5 \\
7.7 \\
8.1 \\
7.4 \\
6.9\end{array}$ & $\begin{array}{r}100.0 \\
16.8 \\
6.9 \\
7.0 \\
7.2 \\
7.3 \\
7.1 \\
6.5 \\
5.9 \\
5.3 \\
4.8 \\
7.8 \\
7.8 \\
5.3 \\
4.4\end{array}$ & $\begin{array}{r}100.0 \\
16.4 \\
6.6 \\
6.7 \\
7.6 \\
7.5 \\
7.3 \\
6.5 \\
5.9 \\
5.3 \\
4.9 \\
7.8 \\
7.8 \\
5.3 \\
4.4\end{array}$ \\
\hline 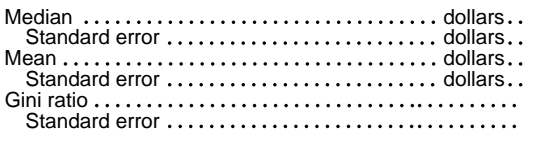 & $\begin{array}{r}34076 \\
197 \\
44938 \\
246 \\
.444 \\
.0039\end{array}$ & $\begin{array}{r}29 \\
093 \\
135 \\
36 \\
729 \\
181 \\
.418 \\
.0039\end{array}$ & $\begin{array}{r}29219 \\
134 \\
36 \quad 915 \\
181 \\
.414 \\
.0039\end{array}$ & $\begin{array}{r}3031 \\
166 \\
41160 \\
251 \\
.503 \\
.0038\end{array}$ & $\begin{array}{r}31082 \\
171 \\
42520 \\
279 \\
.511 \\
.0040\end{array}$ & $\begin{array}{r}32819 \\
215 \\
44644 \\
286 \\
.509 \\
.0039\end{array}$ & $\begin{array}{r}303 \\
193 \\
42238 \\
277 \\
.514 \\
.0040\end{array}$ & $\begin{array}{r}28393 \\
173 \\
36569 \\
207 \\
.490 \\
.0039\end{array}$ & $\begin{array}{r}28535 \\
170 \\
36 \quad 756 \\
206 \\
.486 \\
.0039\end{array}$ \\
\hline Quintile Measures & & & & & & & & & \\
\hline 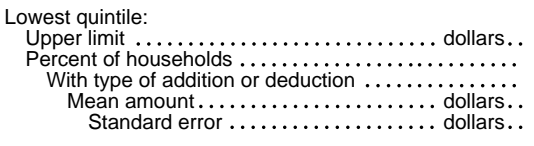 & $\begin{array}{r}14420 \\
20.0 \\
(X) \\
(X) \\
(X)\end{array}$ & $\begin{array}{r}13408 \\
20.0 \\
(X) \\
(X) \\
(X)\end{array}$ & $\begin{array}{r}13921 \\
20.0 \\
(X) \\
(X) \\
(X)\end{array}$ & $\begin{array}{rr}7654 \\
20.0 \\
17 \quad 144 \\
9666 \\
& 73\end{array}$ & $\begin{array}{r}7679 \\
20.0 \\
697 \\
-110 \\
112\end{array}$ & $\begin{array}{r}7851 \\
20.0 \\
412 \\
1386 \\
70\end{array}$ & $\begin{array}{r}7410 \\
20.0 \\
4814 \\
314 \\
5\end{array}$ & $\begin{array}{r}7351 \\
20.0 \\
423 \\
443 \\
142\end{array}$ & $\begin{array}{r}7756 \\
20.0 \\
2794 \\
546 \\
16\end{array}$ \\
\hline 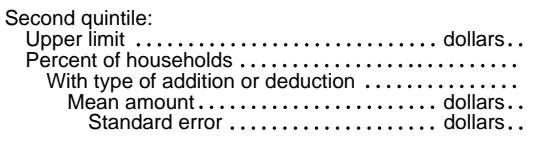 & $\begin{array}{r}26966 \\
20.0 \\
(X) \\
(X) \\
(X)\end{array}$ & $\begin{array}{r}23610 \\
20.0 \\
(X) \\
(X) \\
(X)\end{array}$ & $\begin{array}{rl}23 & 831 \\
20.0 \\
\\
\\
\\
\\
\\
\\
\\
(X) \\
(X) \\
(X)\end{array}$ & $\begin{array}{rr}22 & 950 \\
20.0 \\
10 & 031 \\
9 & 354 \\
102\end{array}$ & $\begin{array}{r}23086 \\
20.0 \\
1653 \\
795 \\
89\end{array}$ & $\begin{array}{rr}24 & 400 \\
20.0 \\
6299 \\
2 \quad 054 \\
22\end{array}$ & $\begin{array}{rr}22 & 891 \\
20.0 \\
15 & 137 \\
1 & 197 \\
& 8\end{array}$ & $\begin{array}{rr}21 & 450 \\
& 20.0 \\
13 & 583 \\
1 & 017 \\
& 9\end{array}$ & $\begin{array}{r}21834 \\
20.0 \\
6683 \\
1650 \\
\\
18\end{array}$ \\
\hline 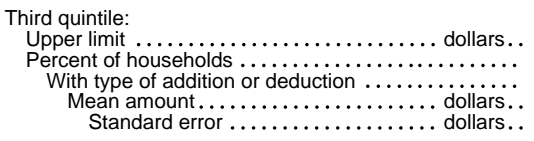 & $\begin{array}{rr}42 & 012 \\
20.0 \\
(X) \\
\\
\\
\\
\\
\\
(X) \\
(X)\end{array}$ & $\begin{array}{r}35288 \\
20.0 \\
(X) \\
(X) \\
(X)\end{array}$ & $\begin{array}{rl}35 & 397 \\
20.0 \\
(X) \\
\\
\\
\\
\\
\\
(X) \\
(X)\end{array}$ & $\begin{array}{rr}39659 \\
20.0 \\
6685 \\
7806 \\
130\end{array}$ & $\begin{array}{rr}39 & 940 \\
20.0 \\
2489 \\
1258 \\
& 89\end{array}$ & $\begin{array}{rr}42 & 235 \\
20.0 \\
13412 \\
2807 \\
17\end{array}$ & $\begin{array}{rr}39619 \\
20.0 \\
17691 \\
2292 \\
10\end{array}$ & $\begin{array}{rr}36 & 021 \\
20.0 \\
19353 \\
2528 \\
14\end{array}$ & $\begin{array}{r}36 \quad 127 \\
20.0 \\
3 \quad 799 \\
1057 \\
23\end{array}$ \\
\hline 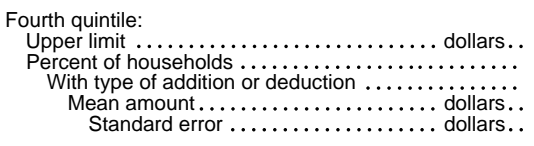 & $\begin{array}{rr}65258 \\
20.0 \\
(X) \\
\\
\\
\\
\\
\\
(X) \\
(X)\end{array}$ & $\begin{array}{r}52481 \\
20.0 \\
(X) \\
(X) \\
(X)\end{array}$ & $\begin{array}{r}52520 \\
20.0 \\
(X) \\
\\
\\
\\
\\
\\
(X) \\
(X)\end{array}$ & $\begin{array}{rr}63 & 123 \\
20.0 \\
4 & 774 \\
7 & 189 \\
& 165\end{array}$ & $\begin{array}{r}63970 \\
20.0 \\
3575 \\
2 \quad 310 \\
98\end{array}$ & $\begin{array}{r}67767 \\
20.0 \\
16710 \\
3877 \\
20\end{array}$ & $\begin{array}{rr}63 \quad 639 \\
20.0 \\
18532 \\
3566 \\
& 14\end{array}$ & $\begin{array}{rr}56502 \\
20.0 \\
19909 \\
5187 \\
23\end{array}$ & $\begin{array}{r}56551 \\
20.0 \\
1095 \\
1302 \\
46\end{array}$ \\
\hline 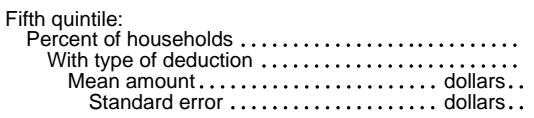 & $\begin{array}{r}20.0 \\
(X) \\
(X) \\
(X)\end{array}$ & $\begin{array}{r}20.0 \\
(X) \\
(X) \\
(X)\end{array}$ & $\begin{array}{r}20.0 \\
(X) \\
(X) \\
(X)\end{array}$ & $\begin{array}{rr}20.0 \\
3 & 758 \\
8 & 073 \\
196\end{array}$ & $\begin{array}{r}20.0 \\
7505 \\
16 \\
371 \\
623\end{array}$ & $\begin{array}{r}20.0 \\
17479 \\
5 \quad 477 \\
28\end{array}$ & $\begin{array}{r}20.0 \\
18923 \\
5997 \\
30\end{array}$ & $\begin{array}{r}20.0 \\
19890 \\
20037 \\
327\end{array}$ & $\begin{array}{r}20.0 \\
488 \\
1201 \\
66\end{array}$ \\
\hline
\end{tabular}


VALUATION OF NONCASH BENEFITS

Table 12. Income Distribution Measures by Definition of Income: 1995-Con.

(Numbers in thousands. Households as of March of the following year. For meaning of symbols, see text)

\begin{tabular}{|c|c|c|c|c|c|c|c|c|c|}
\hline \multirow{4}{*}{ Characteristic } & \multicolumn{9}{|c|}{ After taxes-con. } \\
\hline & \multirow[b]{2}{*}{$\begin{array}{r}\text { Definition } 7 \\
\text { less } \\
\text { State } \\
\text { income } \\
\text { taxes }\end{array}$} & \multirow{2}{*}{$\begin{array}{r}\text { Definition } 8 \\
\text { plus } \\
\text { nonmeans- } \\
\text { tested } \\
\text { government } \\
\text { cash } \\
\text { transfers }\end{array}$} & \multirow[b]{2}{*}{$\begin{array}{r}\text { Definition } 9 \\
\text { plus } \\
\text { medicare }\end{array}$} & \multirow[b]{2}{*}{$\begin{array}{r}\text { Definition } 10 \\
\text { plus } \\
\text { regular-price } \\
\text { school } \\
\text { lunches }\end{array}$} & \multirow[b]{2}{*}{$\begin{array}{r}\text { Definition } 11 \\
\text { plus } \\
\text { means-tested } \\
\text { government } \\
\text { cash } \\
\text { transfers }\end{array}$} & \multirow[b]{2}{*}{$\begin{array}{r}\text { Definition } 12 \\
\text { plus } \\
\text { medicaid }\end{array}$} & \multicolumn{2}{|c|}{$\begin{array}{l}\text { Definition } 13 \text { plus other } \\
\text { means-tested government- }\end{array}$} & \multirow{2}{*}{$\begin{array}{r}\text { Definition } 14 \\
\text { plus } \\
\text { net } \\
\text { imputed } \\
\text { return } \\
\text { on equity } \\
\text { in own } \\
\text { home }\end{array}$} \\
\hline & & & & & & & $\begin{array}{l}\text { Noncash } \\
\text { transfers }\end{array}$ & $\begin{array}{r}\text { Noncash } \\
\text { transfers } \\
\text { less medical } \\
\text { programs }\end{array}$ & \\
\hline & 8 & 9 & 10 & 11 & 12 & 13 & 14 & $14 a$ & 15 \\
\hline \multicolumn{10}{|l|}{ ALL HOUSEHOLDS } \\
\hline 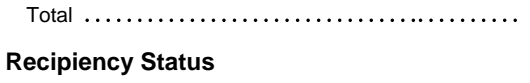 & 99627 & 99627 & 99627 & 99627 & 99627 & 99627 & 99627 & 99627 & 99627 \\
\hline 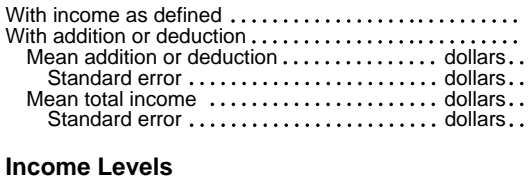 & $\begin{array}{rr}93 \quad 022 \\
64 \quad 827 \\
2296 \\
26 \\
44 \quad 052 \\
245\end{array}$ & $\begin{array}{rr}97 & 510 \\
37 & 786 \\
8 & 930 \\
& 54 \\
31 & 024 \\
& 232\end{array}$ & $\begin{array}{rr}97 & 629 \\
23 & 259 \\
5 & 004 \\
& 26 \\
34 & 655 \\
& 298\end{array}$ & $\begin{array}{rr}97 \quad 646 \\
12 \quad 663 \\
& 88 \\
& 1 \\
57 \quad 171 \\
& 655\end{array}$ & $\begin{array}{rr}99 & 041 \\
8 & 306 \\
4 \quad 690 \\
& 68 \\
19 & 596 \\
& 403\end{array}$ & $\begin{array}{rr}99 & 041 \\
10 & 207 \\
2 & 796 \\
& 38 \\
31 \quad 942 \\
& 454\end{array}$ & $\begin{array}{rr}99 & 224 \\
15 & 750 \\
1876 \\
22 \\
21 \quad 925 \\
206\end{array}$ & $\begin{array}{rr}99 & 224 \\
30 & 101 \\
4 & 815 \\
& 26 \\
15 & 056 \\
& 342\end{array}$ & $\begin{array}{rr}99 & 419 \\
65 & 139 \\
3 & 370 \\
30 \\
50 \quad 829 \\
256\end{array}$ \\
\hline 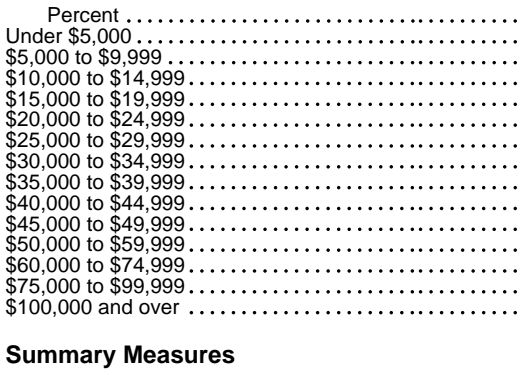 & $\begin{array}{r}100.0 \\
16.4 \\
6.7 \\
6.9 \\
7.8 \\
7.9 \\
7.5 \\
6.7 \\
6.1 \\
5.4 \\
4.8 \\
7.9 \\
7.3 \\
4.7 \\
3.8\end{array}$ & $\begin{array}{r}100.0 \\
6.0 \\
7.6 \\
8.6 \\
9.1 \\
8.8 \\
8.6 \\
7.6 \\
6.9 \\
6.1 \\
5.3 \\
8.5 \\
7.9 \\
5.1 \\
4.0\end{array}$ & $\begin{array}{r}100.0 \\
5.8 \\
6.4 \\
7.1 \\
8.9 \\
9.0 \\
8.7 \\
8.1 \\
7.4 \\
6.5 \\
5.7 \\
8.8 \\
8.2 \\
5.3 \\
4.1\end{array}$ & $\begin{array}{r}100.0 \\
5.8 \\
6.4 \\
7.1 \\
8.9 \\
9.0 \\
8.7 \\
8.1 \\
7.4 \\
6.5 \\
5.7 \\
8.8 \\
8.2 \\
5.3 \\
4.1\end{array}$ & $\begin{array}{r}100.0 \\
3.6 \\
7.4 \\
7.4 \\
9.1 \\
9.1 \\
8.7 \\
8.2 \\
7.6 \\
6.5 \\
5.7 \\
8.9 \\
8.2 \\
5.4 \\
4.1\end{array}$ & $\begin{array}{r}100.0 \\
3.6 \\
7.1 \\
7.2 \\
8.9 \\
9.2 \\
8.9 \\
8.2 \\
7.7 \\
6.6 \\
5.8 \\
9.0 \\
8.3 \\
5.4 \\
4.1\end{array}$ & $\begin{array}{r}100.0 \\
2.7 \\
6.4 \\
7.6 \\
9.3 \\
9.4 \\
9.1 \\
8.3 \\
7.8 \\
6.6 \\
5.8 \\
9.0 \\
8.3 \\
5.4 \\
4.1\end{array}$ & $\begin{array}{r}100.0 \\
2.7 \\
7.8 \\
9.9 \\
9.6 \\
9.2 \\
8.8 \\
7.7 \\
7.1 \\
6.2 \\
5.3 \\
8.6 \\
7.9 \\
5.2 \\
4.0\end{array}$ & $\begin{array}{r}100.0 \\
2.2 \\
5.6 \\
7.3 \\
8.6 \\
9.1 \\
8.7 \\
8.1 \\
7.8 \\
6.9 \\
6.1 \\
9.4 \\
9.1 \\
6.4 \\
4.8\end{array}$ \\
\hline 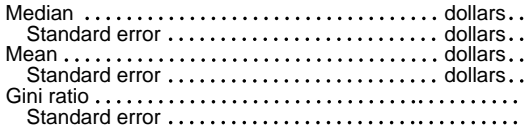 & $\begin{array}{r}27772 \\
163 \\
35262 \\
192 \\
.481 \\
.0038\end{array}$ & $\begin{array}{r}30892 \\
156 \\
38 \quad 649 \\
188 \\
.424 \\
.0039\end{array}$ & $\begin{array}{r}32549 \\
146 \\
39 \quad 817 \\
188 \\
.412 \\
.0038\end{array}$ & $\begin{array}{r}32563 \\
146 \\
39828 \\
188 \\
.412 \\
.0038\end{array}$ & $\begin{array}{r}32761 \\
144 \\
40 \quad 219 \\
187 \\
.404 \\
.0038\end{array}$ & $\begin{array}{r}33149 \\
142 \\
40 \quad 506 \\
187 \\
.400 \\
.0038\end{array}$ & $\begin{array}{r}3306 \\
143 \\
40802 \\
186 \\
.394 \\
.0038\end{array}$ & 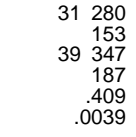 & $\begin{array}{r}35259 \\
154 \\
43006 \\
190 \\
.388 \\
.0038\end{array}$ \\
\hline Quintile Measures & & & & & & & & & \\
\hline 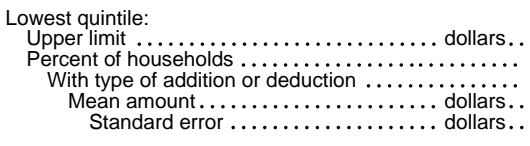 & $\begin{array}{r}7700 \\
20.0 \\
2323 \\
98 \\
8\end{array}$ & $\begin{array}{r}13785 \\
20.0 \\
10441 \\
6802 \\
47\end{array}$ & $\begin{array}{r}15382 \\
20.0 \\
4 \quad 785 \\
2015 \\
28\end{array}$ & $\begin{array}{r}15384 \\
20.0 \\
354 \\
81 \\
3\end{array}$ & $\begin{array}{r}15855 \\
20.0 \\
4 \quad 823 \\
4 \quad 161 \\
62\end{array}$ & $\begin{array}{r}16219 \\
20.0 \\
2776 \\
1222 \\
28\end{array}$ & $\begin{array}{r}16758 \\
20.0 \\
7014 \\
2244 \\
\\
34\end{array}$ & $\begin{array}{r}14816 \\
20.0 \\
8110 \\
2705 \\
26\end{array}$ & $\begin{array}{r}17933 \\
20.0 \\
7327 \\
1885 \\
66\end{array}$ \\
\hline 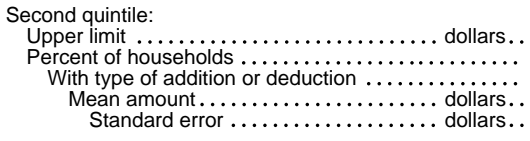 & $\begin{array}{r}21354 \\
20.0 \\
13247 \\
389 \\
5\end{array}$ & $\begin{array}{r}24957 \\
20.0 \\
9233 \\
9588 \\
86\end{array}$ & $\begin{array}{r}26564 \\
20.0 \\
6282 \\
4 \quad 630 \\
\\
\\
26\end{array}$ & $\begin{array}{r}26570 \\
20.0 \\
1215 \\
81 \\
2\end{array}$ & $\begin{array}{r}26837 \\
20.0 \\
1536 \\
4994 \\
169\end{array}$ & $\begin{array}{r}27195 \\
20.0 \\
2875 \\
2703 \\
46\end{array}$ & $\begin{array}{r}27429 \\
20.0 \\
4439 \\
1 \quad 721 \\
\\
41\end{array}$ & $\begin{array}{r}25434 \\
20.0 \\
8 \quad 870 \\
5099 \\
41\end{array}$ & $\begin{array}{r}29127 \\
20.0 \\
10540 \\
2448 \\
48\end{array}$ \\
\hline 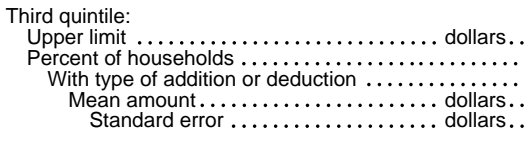 & $\begin{array}{r}35008 \\
20.0 \\
15 \quad 857 \\
1014 \\
8\end{array}$ & $\begin{array}{r}37682 \\
20.0 \\
7446 \\
9584 \\
\\
116\end{array}$ & $\begin{array}{r}38937 \\
20.0 \\
5238 \\
6259 \\
49\end{array}$ & $\begin{array}{r}38950 \\
20.0 \\
2528 \\
85 \\
1\end{array}$ & $\begin{array}{r}39096 \\
20.0 \\
1000 \\
5 \quad 268 \\
259\end{array}$ & $\begin{array}{r}39410 \\
20.0 \\
2009 \\
3 \quad 620 \\
\\
\quad 85\end{array}$ & $\begin{array}{r}39537 \\
20.0 \\
2624 \\
1447 \\
\\
\quad 49\end{array}$ & $\begin{array}{r}37948 \\
20.0 \\
6081 \\
5 \quad 965 \\
59\end{array}$ & $\begin{array}{r}41760 \\
20.0 \\
13685 \\
2725 \\
45\end{array}$ \\
\hline 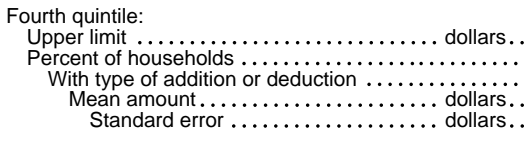 & $\begin{array}{r}54274 \\
20.0 \\
16 \quad 649 \\
1960 \\
12\end{array}$ & $\begin{array}{r}56093 \\
20.0 \\
5 \quad 828 \\
9517 \\
160\end{array}$ & $\begin{array}{rr}56986 \\
20.0 \\
3445 \\
6486 \\
& 61\end{array}$ & $\begin{array}{r}57002 \\
20.0 \\
3 \quad 953 \\
90 \\
1\end{array}$ & $\begin{array}{r}57 \quad 110 \\
20.0 \\
548 \\
6382 \\
382\end{array}$ & $\begin{array}{r}57330 \\
20.0 \\
1397 \\
4015 \\
131\end{array}$ & $\begin{array}{r}57363 \\
20.0 \\
1301 \\
1421 \\
\\
\\
75\end{array}$ & $\begin{array}{r}56239 \\
20.0 \\
3900 \\
5 \quad 912 \\
80\end{array}$ & $\begin{array}{r}60300 \\
20.0 \\
15898 \\
3150 \\
50\end{array}$ \\
\hline 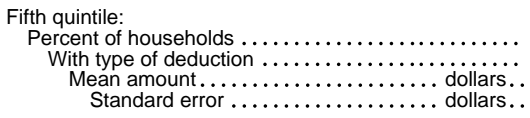 & $\begin{array}{r}20.0 \\
16751 \\
5657 \\
87\end{array}$ & $\begin{array}{r}20.0 \\
4839 \\
10553 \\
255\end{array}$ & $\begin{array}{rr} & 20.0 \\
3 & 108 \\
6 & 412 \\
& 72\end{array}$ & $\begin{array}{r}20.0 \\
4 \quad 612 \\
89 \\
1\end{array}$ & $\begin{array}{r}20.0 \\
399 \\
6 \quad 142 \\
484\end{array}$ & 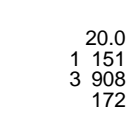 & $\begin{array}{r}20.0 \\
371 \\
1393 \\
133\end{array}$ & $\begin{array}{r}20.0 \\
3141 \\
5872 \\
87\end{array}$ & $\begin{array}{r}20.0 \\
17689 \\
5231 \\
82\end{array}$ \\
\hline
\end{tabular}


VALUATION OF NONCASH BENEFITS

Table 12. Income Distribution Measures by Definition of Income: 1995-Con.

(Numbers in thousands. Households as of March of the following year. For meaning of symbols, see text)

\begin{tabular}{|c|c|c|c|c|c|c|c|c|c|}
\hline \multirow{4}{*}{ Characteristic } & \multicolumn{3}{|c|}{ Money income- } & \multicolumn{3}{|c|}{ Before taxes } & \multicolumn{3}{|c|}{ After taxes } \\
\hline & \multirow[b]{2}{*}{$\begin{array}{r}\text { Excluding } \\
\text { capital } \\
\text { gains } \\
\text { (current } \\
\text { official } \\
\text { measure) } \\
\end{array}$} & \multicolumn{2}{|c|}{$\begin{array}{l}\text { Definition } 1 \text { less taxes } \\
\text { plus capital gains (losses) }\end{array}$} & \multicolumn{2}{|c|}{ Money income- } & \multirow{2}{*}{$\begin{array}{r}\text { Definition } 3 \\
\text { plus } \\
\text { health } \\
\text { insurance } \\
\text { supplements } \\
\text { to wage or } \\
\text { salary } \\
\text { income }\end{array}$} & \multirow[b]{2}{*}{$\begin{array}{r}\text { Definition } 4 \\
\text { less } \\
\text { Social } \\
\text { Security } \\
\text { payroll } \\
\text { taxes } \\
\end{array}$} & \multirow[b]{2}{*}{$\begin{array}{r}\text { Definition } 5 \\
\text { less } \\
\text { Federal } \\
\text { income } \\
\text { taxes }\end{array}$} & \multirow[b]{2}{*}{$\begin{array}{r}\text { Definition } 6 \\
\text { plus } \\
\text { Earned } \\
\text { Income } \\
\text { Tax } \\
\text { Credit }\end{array}$} \\
\hline & & $\begin{array}{r}\text { Without } \\
\text { EITC } \\
\end{array}$ & With EITC & $\begin{array}{r}\text { Definition } 1 \\
\text { less } \\
\text { government } \\
\text { transfers } \\
\end{array}$ & $\begin{array}{r}\text { Definition } 2 \\
\text { plus } \\
\text { capital } \\
\text { gains } \\
\text { (losses) } \\
\end{array}$ & & & & \\
\hline & 1 & $1 \mathrm{a}$ & $1 \mathrm{~b}$ & 2 & 3 & 4 & 5 & 6 & 7 \\
\hline \multicolumn{10}{|l|}{$\begin{array}{l}\text { HOUSEHOLDS WITH FEMALE } \\
\text { HOUSEHOLDER, NO HUSBAND } \\
\text { PRESENT, WITH RELATED } \\
\text { CHILDREN UNDER } 18\end{array}$} \\
\hline \multicolumn{9}{|l|}{ Recipiency Status } & 8751 \\
\hline 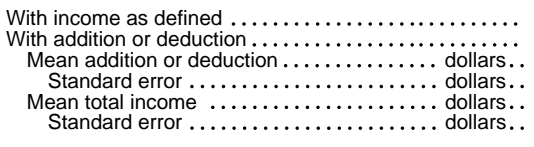 & $\begin{array}{rl}8 & 670 \\
(X) \\
(X) \\
(X) \\
(X) \\
(X)\end{array}$ & $\begin{array}{rl}8 & 670 \\
(X) \\
(X) \\
(X) \\
(X) \\
(X) \\
(X)\end{array}$ & $\begin{array}{rl}8 & 670 \\
(X) \\
(X) \\
(X) \\
(X) \\
(X) \\
(X)\end{array}$ & $\begin{array}{rl}7 & 653 \\
4 & 467 \\
6 & 188 \\
117 \\
13 & 513 \\
& 442\end{array}$ & $\begin{array}{rl}7 & 653 \\
666 \\
5590 \\
1 & 254 \\
59 & 529 \\
5 & 353\end{array}$ & $\begin{array}{rl}7 & 653 \\
3 & 630 \\
3 & 327 \\
49 & 42 \\
39 & 149 \\
& 840\end{array}$ & $\begin{array}{rl}7 & 653 \\
6 & 728 \\
1 & 683 \\
27 \\
26 & 27 \\
& 601 \\
& 646\end{array}$ & $\begin{array}{rl}7 & 659 \\
4 & 455 \\
3 & 241 \\
& 258 \\
34 & 049 \\
& 671\end{array}$ & $\begin{array}{rl}7 & 659 \\
4 & 648 \\
1622 \\
\quad 20 \\
20 \quad 493 \\
\quad 483\end{array}$ \\
\hline \multicolumn{10}{|l|}{ Income Levels } \\
\hline 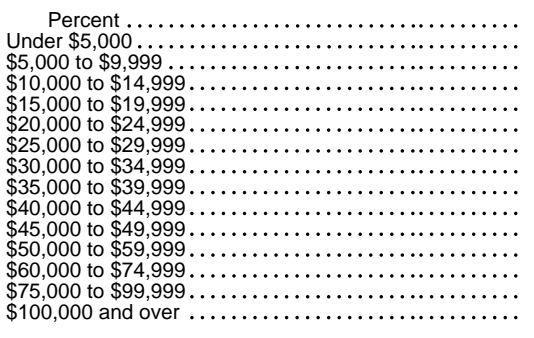 & $\begin{array}{r}100.0 \\
10.8 \\
17.0 \\
14.8 \\
11.5 \\
9.0 \\
7.6 \\
6.6 \\
6.1 \\
3.7 \\
3.0 \\
4.2 \\
2.9 \\
1.5 \\
1.3\end{array}$ & $\begin{array}{r}100.0 \\
11.5 \\
17.8 \\
16.5 \\
12.8 \\
9.8 \\
8.3 \\
7.0 \\
4.2 \\
3.7 \\
2.3 \\
2.9 \\
1.5 \\
1.0 \\
.7\end{array}$ & $\begin{array}{r}100.0 \\
10.3 \\
15.5 \\
14.7 \\
15.0 \\
11.3 \\
8.8 \\
7.2 \\
4.7 \\
3.9 \\
2.5 \\
3.0 \\
1.5 \\
1.0 \\
.7\end{array}$ & $\begin{array}{r}100.0 \\
27.2 \\
10.4 \\
11.1 \\
9.2 \\
8.6 \\
7.1 \\
6.2 \\
5.3 \\
3.5 \\
2.5 \\
3.7 \\
2.7 \\
1.3 \\
1.2\end{array}$ & $\begin{array}{r}100.0 \\
27.2 \\
10.3 \\
11.1 \\
9.3 \\
8.3 \\
7.0 \\
6.4 \\
5.0 \\
3.7 \\
2.5 \\
3.5 \\
2.7 \\
1.6 \\
1.2\end{array}$ & $\begin{array}{r}100.0 \\
27.0 \\
9.7 \\
10.2 \\
8.8 \\
7.9 \\
7.1 \\
6.5 \\
5.1 \\
3.8 \\
3.4 \\
3.9 \\
3.3 \\
1.9 \\
1.3 \\
\end{array}$ & $\begin{array}{r}100.0 \\
27.9 \\
10.2 \\
10.7 \\
9.0 \\
8.1 \\
7.4 \\
6.4 \\
4.7 \\
4.0 \\
2.5 \\
3.8 \\
2.5 \\
1.7 \\
1.1\end{array}$ & $\begin{array}{r}100.0 \\
27.9 \\
10.3 \\
11.0 \\
9.7 \\
9.1 \\
7.7 \\
6.7 \\
4.6 \\
3.4 \\
2.2 \\
3.6 \\
1.9 \\
1.1 \\
.8\end{array}$ & $\begin{array}{r}100.0 \\
25.9 \\
8.8 \\
10.5 \\
10.9 \\
9.8 \\
8.9 \\
6.7 \\
4.9 \\
3.6 \\
2.4 \\
3.7 \\
1.9 \\
1.1 \\
.8\end{array}$ \\
\hline \multicolumn{10}{|l|}{ Summary Measures } \\
\hline 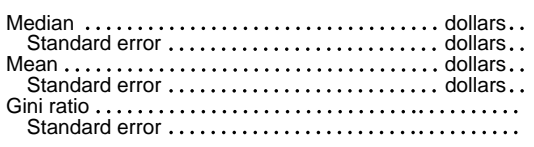 & $\begin{array}{r}17936 \\
409 \\
24508 \\
466 \\
.454 \\
.0134\end{array}$ & $\begin{array}{r}16600 \\
303 \\
21504 \\
363 \\
.433 \\
.0134\end{array}$ & $\begin{array}{r}18039 \\
287 \\
22365 \\
362 \\
.415 \\
.0132\end{array}$ & $\begin{array}{r}15584 \\
395 \\
21349 \\
473 \\
.525 \\
.0129\end{array}$ & $\begin{array}{r}15651 \\
393 \\
21774 \\
534 \\
.532 \\
.0135\end{array}$ & $\begin{array}{r}16783 \\
456 \\
23154 \\
549 \\
.532 \\
.0133\end{array}$ & $\begin{array}{r}15693 \\
431 \\
21860 \\
534 \\
.534 \\
.0135\end{array}$ & $\begin{array}{r}15400 \\
395 \\
20210 \\
417 \\
.516 \\
.0127\end{array}$ & $\begin{array}{r}17191 \\
367 \\
21072 \\
416 \\
.496 \\
.0127\end{array}$ \\
\hline Quintile Measures & & & & & & & & & \\
\hline 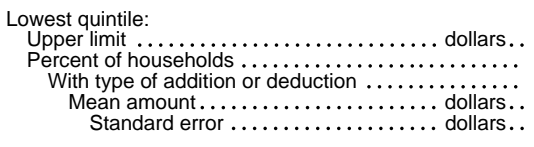 & $\begin{array}{r}14420 \\
41.3 \\
(X) \\
(X) \\
(X)\end{array}$ & $\begin{array}{r}13408 \\
40.6 \\
(X) \\
(X) \\
(X)\end{array}$ & $\begin{array}{r}13921 \\
37.3 \\
(X) \\
(X) \\
(X)\end{array}$ & $\begin{array}{r}7654 \\
33.0 \\
2413 \\
6513 \\
\\
\quad 141\end{array}$ & $\begin{array}{r}7679 \\
33.1 \\
21 \\
(\mathrm{~B}) \\
(\mathrm{B})\end{array}$ & $\begin{array}{r}7851 \\
32.7 \\
38 \\
(B) \\
(B)\end{array}$ & $\begin{array}{r}7410 \\
33.1 \\
1271 \\
272 \\
9\end{array}$ & $\begin{array}{r}7351 \\
32.7 \\
25 \\
(B) \\
\text { (B) }\end{array}$ & $\begin{array}{r}7756 \\
30.7 \\
744 \\
972 \\
31\end{array}$ \\
\hline 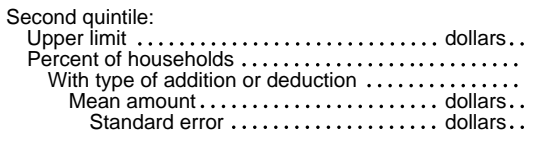 & $\begin{array}{r}26966 \\
24.8 \\
(X) \\
(X) \\
(X)\end{array}$ & $\begin{array}{r}23610 \\
24.9 \\
(X) \\
(X) \\
(X)\end{array}$ & $\begin{array}{r}23831 \\
27.1 \\
(X) \\
(X) \\
(X)\end{array}$ & $\begin{array}{r}22950 \\
30.1 \\
1080 \\
5 \quad 406 \\
269\end{array}$ & $\begin{array}{r}23086 \\
30.5 \\
86 \\
1069 \\
386\end{array}$ & $\begin{array}{r}24400 \\
30.0 \\
1045 \\
2487 \\
54\end{array}$ & $\begin{array}{r}22891 \\
29.5 \\
2389 \\
1035 \\
13\end{array}$ & $\begin{array}{r}21450 \\
29.0 \\
1202 \\
682 \\
24\end{array}$ & $\begin{array}{r}21834 \\
29.4 \\
2224 \\
1999 \\
26\end{array}$ \\
\hline 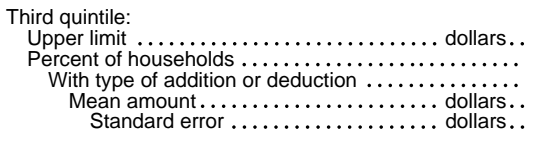 & $\begin{array}{r}42012 \\
18.9 \\
(X) \\
(X) \\
(X)\end{array}$ & $\begin{array}{r}35288 \\
18.5 \\
(X) \\
(X) \\
(X)\end{array}$ & $\begin{array}{r}35397 \\
18.9 \\
(X) \\
(X) \\
(X)\end{array}$ & $\begin{array}{r}39659 \\
21.7 \\
607 \\
5 \quad 789 \\
297\end{array}$ & $\begin{array}{r}39940 \\
21.2 \\
209 \\
1667 \\
303\end{array}$ & $\begin{array}{rr}42 & 235 \\
21.7 \\
1374 \\
3 \quad 080 \\
47\end{array}$ & $\begin{array}{r}39619 \\
21.5 \\
1 \quad 757 \\
2 \quad 041 \\
24\end{array}$ & $\begin{array}{r}36021 \\
21.5 \\
1785 \\
1706 \\
33\end{array}$ & $\begin{array}{r}36 \quad 127 \\
22.7 \\
1209 \\
1381 \\
43\end{array}$ \\
\hline 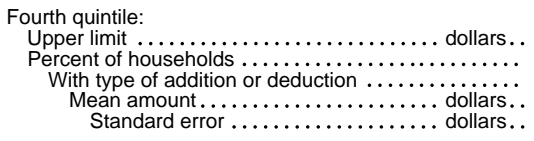 & $\begin{array}{r}65258 \\
10.6 \\
(X) \\
(X) \\
(X)\end{array}$ & $\begin{array}{r}52481 \\
10.9 \\
(X) \\
(X) \\
(X)\end{array}$ & $\begin{array}{r}52520 \\
11.5 \\
(X) \\
(X) \\
(X)\end{array}$ & $\begin{array}{r}63 \quad 123 \\
10.6 \\
246 \\
6778 \\
577\end{array}$ & $\begin{array}{r}63970 \\
10.8 \\
185 \\
2699 \\
342\end{array}$ & $\begin{array}{r}67767 \\
11.2 \\
844 \\
4015 \\
84\end{array}$ & $\begin{array}{r}63639 \\
11.5 \\
936 \\
3 \quad 247 \\
55\end{array}$ & $\begin{array}{r}56502 \\
12.0 \\
1 \quad 034 \\
3 \quad 812 \\
\\
81\end{array}$ & $\begin{array}{r}56551 \\
12.3 \\
378 \\
1501 \\
75\end{array}$ \\
\hline 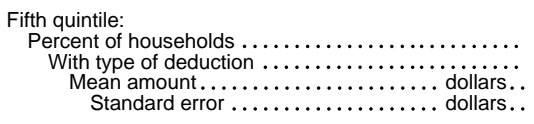 & $\begin{array}{l}4.5 \\
(X) \\
(X) \\
(X)\end{array}$ & $\begin{array}{l}5.1 \\
(X) \\
(X) \\
(X)\end{array}$ & $\begin{array}{l}5.2 \\
(X) \\
(X) \\
(X)\end{array}$ & $\begin{array}{r}4.5 \\
121 \\
7501 \\
1006\end{array}$ & $\begin{array}{r}4.4 \\
165 \\
16944 \\
4794\end{array}$ & $\begin{array}{r}4.4 \\
328 \\
5390 \\
213\end{array}$ & $\begin{array}{r}4.4 \\
376 \\
5005 \\
172\end{array}$ & $\begin{array}{r}4.7 \\
408 \\
16 \quad 231 \\
2600\end{array}$ & $\begin{array}{r}4.9 \\
93 \\
1453 \\
165\end{array}$ \\
\hline
\end{tabular}


VALUATION OF NONCASH BENEFITS

Table 12. Income Distribution Measures by Definition of Income: 1995-Con.

(Numbers in thousands. Households as of March of the following year. For meaning of symbols, see text)

\begin{tabular}{|c|c|c|c|c|c|c|c|c|c|}
\hline \multirow{4}{*}{ Characteristic } & \multicolumn{9}{|c|}{ After taxes-con. } \\
\hline & \multirow[b]{2}{*}{$\begin{array}{r}\text { Definition } 7 \\
\text { less } \\
\text { State } \\
\text { income } \\
\text { taxes }\end{array}$} & \multirow{2}{*}{$\begin{array}{r}\text { Definition } 8 \\
\text { plus } \\
\text { nonmeans- } \\
\text { tested } \\
\text { government } \\
\text { cash } \\
\text { transfers }\end{array}$} & \multirow[b]{2}{*}{$\begin{array}{r}\text { Definition } 9 \\
\text { plus } \\
\text { medicare }\end{array}$} & \multirow[b]{2}{*}{$\begin{array}{r}\text { Definition } 10 \\
\text { plus } \\
\text { regular-price } \\
\text { school } \\
\text { lunches }\end{array}$} & \multirow{2}{*}{$\begin{array}{r}\text { Definition } 11 \\
\text { plus } \\
\text { means-tested } \\
\text { government } \\
\text { cash } \\
\text { transfers }\end{array}$} & \multirow[b]{2}{*}{$\begin{array}{r}\text { Definition } 12 \\
\text { plus } \\
\text { medicaid }\end{array}$} & \multicolumn{2}{|c|}{$\begin{array}{l}\text { Definition } 13 \text { plus other } \\
\text { means-tested government- }\end{array}$} & \multirow{2}{*}{$\begin{array}{r}\text { Definition } 14 \\
\text { plus } \\
\text { net } \\
\text { imputed } \\
\text { return } \\
\text { on equity } \\
\text { in own } \\
\text { home }\end{array}$} \\
\hline & & & & & & & $\begin{array}{l}\text { Noncash } \\
\text { transfers }\end{array}$ & $\begin{array}{r}\text { Noncash } \\
\text { transfers } \\
\text { less medical } \\
\text { programs }\end{array}$ & \\
\hline & 8 & 9 & 10 & 11 & 12 & 13 & 14 & $14 a$ & 15 \\
\hline \multicolumn{10}{|l|}{$\begin{array}{l}\text { HOUSEHOLDS WITH FEMALE } \\
\text { HOUSEHOLDER, NO HUSBAND } \\
\text { PRESENT, WITH RELATED } \\
\text { CHILDREN UNDER } 18\end{array}$} \\
\hline $\begin{array}{l}\text { Total } \ldots \ldots \ldots \ldots \ldots \ldots \ldots \ldots \ldots \ldots \\
\text { Recipiency Status }\end{array}$ & 8751 & 8751 & 8751 & 8751 & 8751 & 8751 & 8751 & 8751 & 8751 \\
\hline 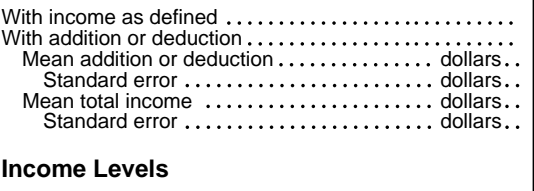 & $\begin{array}{rr}7 & 660 \\
4 & 188 \\
1 & 015 \\
& 81 \\
30 & 900 \\
& 625\end{array}$ & $\begin{array}{rr}7 & 944 \\
2 & 361 \\
5 & 536 \\
171 \\
24 & 111 \\
& 639\end{array}$ & $\begin{array}{rr}7954 \\
531 \\
3933 \\
& 160 \\
34 & 364 \\
1 & 724\end{array}$ & $\begin{array}{rr}7 & 966 \\
1 & 828 \\
& 80 \\
1 \\
37830 \\
1 & 037\end{array}$ & $\begin{array}{rr}8 & 675 \\
2 & 964 \\
4 & 915 \\
& 102 \\
14 & 355 \\
& 398\end{array}$ & $\begin{array}{rr}8 & 675 \\
2 & 476 \\
2 & 797 \\
& 81 \\
25 & 399 \\
& 799\end{array}$ & \begin{tabular}{rr|}
8 & 739 \\
5 & 294 \\
2 & 659 \\
& 48 \\
19 & 893 \\
& 386
\end{tabular} & \begin{tabular}{rr|}
8 & 739 \\
2 & 709 \\
3 & 327 \\
& 86 \\
12 & 885 \\
980 & 98
\end{tabular} & $\begin{array}{rr}8 & 742 \\
3 & 139 \\
2 & 317 \\
125 \\
36 \quad 398 \\
683\end{array}$ \\
\hline 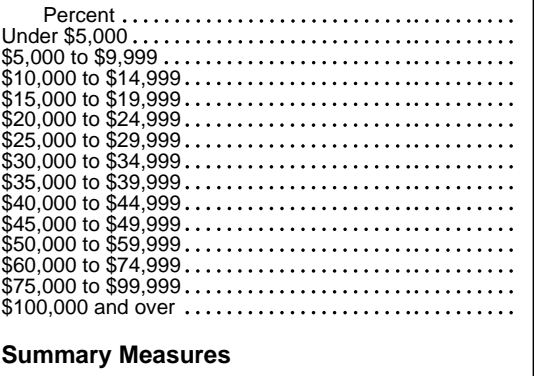 & $\begin{array}{r}100.0 \\
25.9 \\
9.0 \\
10.5 \\
11.3 \\
10.5 \\
8.6 \\
6.8 \\
4.8 \\
3.4 \\
2.6 \\
3.4 \\
1.7 \\
1.0 \\
.7\end{array}$ & $\begin{array}{r}100.0 \\
21.4 \\
10.0 \\
10.7 \\
11.8 \\
10.4 \\
8.7 \\
7.6 \\
4.9 \\
3.8 \\
3.0 \\
3.7 \\
2.0 \\
1.1 \\
.7\end{array}$ & $\begin{array}{r}100.0 \\
21.3 \\
9.8 \\
10.6 \\
11.8 \\
10.6 \\
8.4 \\
7.7 \\
5.0 \\
3.6 \\
3.3 \\
3.8 \\
2.1 \\
1.2 \\
.7\end{array}$ & $\begin{array}{r}100.0 \\
21.3 \\
9.9 \\
10.6 \\
11.8 \\
10.5 \\
8.4 \\
7.7 \\
5.1 \\
3.6 \\
3.3 \\
3.8 \\
2.1 \\
1.2 \\
.7\end{array}$ & $\begin{array}{r}100.0 \\
10.2 \\
15.0 \\
12.7 \\
13.6 \\
11.1 \\
8.8 \\
7.8 \\
5.7 \\
3.7 \\
3.4 \\
3.9 \\
2.1 \\
1.3 \\
.7\end{array}$ & $\begin{array}{r}100.0 \\
10.0 \\
13.6 \\
12.0 \\
13.0 \\
12.2 \\
9.1 \\
8.1 \\
5.9 \\
4.1 \\
3.4 \\
4.1 \\
2.3 \\
1.4 \\
.8\end{array}$ & $\begin{array}{r}100.0 \\
3.5 \\
10.9 \\
14.8 \\
15.8 \\
13.4 \\
10.6 \\
7.8 \\
6.5 \\
4.4 \\
3.4 \\
4.3 \\
2.3 \\
1.5 \\
.8\end{array}$ & $\begin{array}{r}100.0 \\
3.5 \\
11.2 \\
18.0 \\
16.0 \\
12.7 \\
10.0 \\
7.9 \\
5.6 \\
4.0 \\
3.0 \\
4.1 \\
2.1 \\
1.2 \\
.7\end{array}$ & $\begin{array}{r}100.0 \\
3.2 \\
10.5 \\
14.6 \\
15.4 \\
13.2 \\
10.5 \\
7.3 \\
7.3 \\
4.4 \\
3.5 \\
4.8 \\
2.6 \\
1.8 \\
.8\end{array}$ \\
\hline 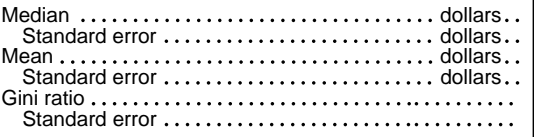 & $\begin{array}{r}17086 \\
357 \\
20587 \\
386 \\
.491 \\
.0125\end{array}$ & $\begin{array}{r}18306 \\
342 \\
22081 \\
390 \\
.470 \\
.0125\end{array}$ & 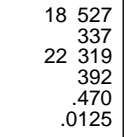 & $\begin{array}{r}18539 \\
336 \\
22 \quad 336 \\
392 \\
.470 \\
.0125\end{array}$ & $\begin{array}{r}19400 \\
312 \\
24000 \\
381 \\
.421 \\
.0130\end{array}$ & $\begin{array}{r}20569 \\
329 \\
24 \quad 792 \\
383 \\
.413 \\
.0128\end{array}$ & $\begin{array}{r}21786 \\
285 \\
26 \quad 400 \\
372 \\
.367 \\
.0129\end{array}$ & $\begin{array}{r}20529 \\
299 \\
25370 \\
366 \\
.370 \\
.0131\end{array}$ & $\begin{array}{r}22360 \\
300 \\
27 \quad 231 \\
382 \\
.368 \\
.0129\end{array}$ \\
\hline \multicolumn{10}{|l|}{ Quintile Measures } \\
\hline 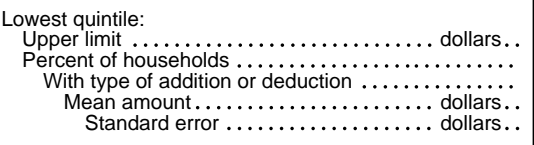 & $\begin{array}{r}7700 \\
30.6 \\
154 \\
68 \\
8\end{array}$ & $\begin{array}{r}13785 \\
39.3 \\
874 \\
3 \quad 889 \\
158\end{array}$ & $\begin{array}{r}15382 \\
42.7 \\
143 \\
1467 \\
152\end{array}$ & $\begin{array}{r}15384 \\
42.7 \\
177 \\
81 \\
4\end{array}$ & $\begin{array}{r}15855 \\
40.5 \\
2104 \\
4570 \\
95\end{array}$ & $\begin{array}{r}16219 \\
38.8 \\
876 \\
1433 \\
49\end{array}$ & $\begin{array}{r}16758 \\
35.6 \\
2686 \\
3 \quad 154 \\
67\end{array}$ & $\begin{array}{rl}14 & 816 \\
31.8 \\
648 \\
1614 \\
63\end{array}$ & $\begin{array}{r}17933 \\
37.4 \\
559 \\
1029 \\
172\end{array}$ \\
\hline 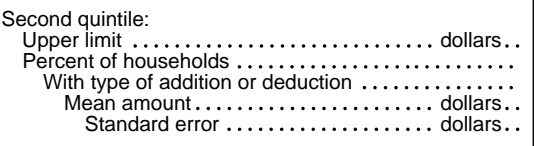 & $\begin{array}{r}21354 \\
29.1 \\
1292 \\
249 \\
9\end{array}$ & $\begin{array}{r}24957 \\
25.0 \\
557 \\
5117 \\
293\end{array}$ & $\begin{array}{r}26564 \\
24.2 \\
99 \\
3932 \\
256\end{array}$ & $\begin{array}{r}26570 \\
24.1 \\
433 \\
76 \\
3\end{array}$ & $\begin{array}{r}26837 \\
25.8 \\
485 \\
5 \quad 629 \\
322\end{array}$ & $\begin{array}{r}27 \quad 195 \\
26.5 \\
830 \\
2917 \\
92\end{array}$ & $\begin{array}{r}27429 \\
28.4 \\
1572 \\
251 \\
281 \\
\\
83\end{array}$ & $\begin{array}{r}25 \quad 434 \\
30.4 \\
1135 \\
2962 \\
90 \\
\\
9\end{array}$ & $\begin{array}{r}29127 \\
28.1 \\
764 \\
1518 \\
156\end{array}$ \\
\hline 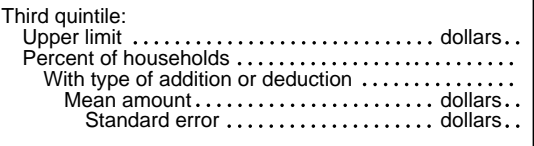 & $\begin{array}{r}35008 \\
22.9 \\
1502 \\
660 \\
17\end{array}$ & $\begin{array}{r}37682 \\
19.2 \\
483 \\
5964 \\
387\end{array}$ & $\begin{array}{rr}38937 \\
17.6 \\
113 \\
4 \quad 624 \\
190\end{array}$ & $\begin{array}{r}38950 \\
17.6 \\
580 \\
77 \\
2\end{array}$ & $\begin{array}{r}39096 \\
17.8 \\
229 \\
4 \quad 814 \\
439\end{array}$ & $\begin{array}{r}39410 \\
18.2 \\
428 \\
3847 \\
199\end{array}$ & $\begin{array}{r}39537 \\
18.8 \\
659 \\
1951 \\
132\end{array}$ & $\begin{array}{r}37948 \\
20.8 \\
529 \\
4965 \\
236\end{array}$ & $\begin{array}{r}41760 \\
18.1 \\
843 \\
2185 \\
189\end{array}$ \\
\hline 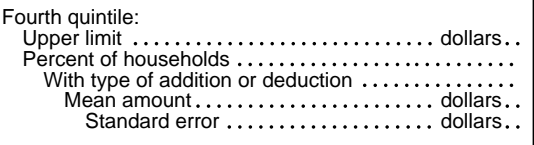 & $\begin{array}{r}54274 \\
12.5 \\
894 \\
1366 \\
44\end{array}$ & $\begin{array}{r}56 \quad 093 \\
11.4 \\
291 \\
7988 \\
575\end{array}$ & $\begin{array}{r}56986 \\
10.6 \\
94 \\
5398 \\
376\end{array}$ & $\begin{array}{r}57002 \\
10.6 \\
401 \\
85 \\
3\end{array}$ & $\begin{array}{r}57 \quad 110 \\
10.8 \\
89 \\
8353 \\
1102\end{array}$ & $\begin{array}{r}57330 \\
11.4 \\
220 \\
4 \quad 615 \\
388\end{array}$ & $\begin{array}{r}57363 \\
11.9 \\
308 \\
1866 \\
216\end{array}$ & $\begin{array}{r}56 \quad 239 \\
11.8 \\
245 \\
4 \quad 843 \\
415\end{array}$ & $\begin{array}{r}60300 \\
11.3 \\
650 \\
2733 \\
255\end{array}$ \\
\hline 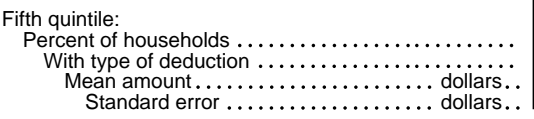 & $\begin{array}{r}4.9 \\
346 \\
4925 \\
900\end{array}$ & $\begin{array}{r}5.0 \\
157 \\
10337 \\
1207\end{array}$ & $\begin{array}{r}4.9 \\
82 \\
587 \\
444\end{array}$ & $\begin{array}{r}4.9 \\
236 \\
86 \\
4\end{array}$ & $\begin{array}{l}5.1 \\
57 \\
(\mathrm{~B}) \\
\text { (B) }\end{array}$ & $\begin{array}{r}5.2 \\
123 \\
4800 \\
832\end{array}$ & $\begin{array}{l}5.3 \\
69 \\
(\mathrm{~B}) \\
\text { (B) }\end{array}$ & $\begin{array}{r}5.2 \\
152 \\
5224 \\
521\end{array}$ & $\begin{array}{r}5.1 \\
323 \\
5939 \\
787\end{array}$ \\
\hline
\end{tabular}




\section{VALUATION OF NONCASH BENEFITS}

Table 12. Income Distribution Measures by Definition of Income: 1995-Con.

(Numbers in thousands. Households as of March of the following year. For meaning of symbols, see text)

\begin{tabular}{|c|c|c|c|c|c|c|c|c|c|}
\hline \multirow{4}{*}{ Characteristic } & \multicolumn{3}{|c|}{ Money income- } & \multicolumn{3}{|c|}{ Before taxes } & \multicolumn{3}{|c|}{ After taxes } \\
\hline & \multirow[b]{2}{*}{$\begin{array}{r}\text { Excluding } \\
\text { capital } \\
\text { gains } \\
\text { (current } \\
\text { official } \\
\text { measure) }\end{array}$} & \multicolumn{2}{|c|}{$\begin{array}{l}\text { Definition } 1 \text { less taxes } \\
\text { plus capital gains (losses) }\end{array}$} & \multicolumn{2}{|c|}{ Money income- } & \multirow{2}{*}{$\begin{array}{r}\text { Definition } 3 \\
\text { plus } \\
\text { health } \\
\text { insurance } \\
\text { supplements } \\
\text { to wage or } \\
\text { salary } \\
\text { income }\end{array}$} & \multirow[b]{2}{*}{$\begin{array}{r}\text { Definition } 4 \\
\text { less } \\
\text { Social } \\
\text { Security } \\
\text { payroll } \\
\text { taxes }\end{array}$} & \multirow[b]{2}{*}{$\begin{array}{r}\text { Definition } 5 \\
\text { less } \\
\text { Federal } \\
\text { income } \\
\text { taxes }\end{array}$} & \multirow[b]{2}{*}{$\begin{array}{r}\text { Definition } 6 \\
\text { plus } \\
\text { Earned } \\
\text { Income } \\
\text { Tax } \\
\text { Credit }\end{array}$} \\
\hline & & $\begin{array}{l}\text { Without } \\
\text { EITC }\end{array}$ & With EITC & $\begin{array}{r}\text { Definition } 1 \\
\text { less } \\
\text { government } \\
\text { transfers }\end{array}$ & $\begin{array}{r}\text { Definition } 2 \\
\text { plus } \\
\text { capital } \\
\text { gains } \\
\text { (losses) }\end{array}$ & & & & \\
\hline & 1 & $1 a$ & $1 b$ & 2 & 3 & 4 & 5 & 6 & 7 \\
\hline \multicolumn{10}{|l|}{$\begin{array}{l}\text { HOUSEHOLDS WITH MEMBERS } 65 \\
\text { YEARS OLD AND OVER }\end{array}$} \\
\hline $\begin{array}{l}\text { Total } \ldots \ldots \ldots \ldots \ldots \ldots \ldots \ldots \ldots \ldots \ldots \\
\text { Recipiency Status }\end{array}$ & 23732 & 23732 & 23732 & 23732 & 23732 & 23732 & 23732 & 23732 & 23732 \\
\hline 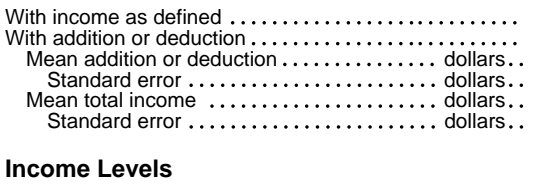 & $23 \begin{aligned} 592 \\
(X) \\
(X) \\
\\
\\
(X) \\
\\
\\
\\
(X) \\
(X)\end{aligned}$ & $\begin{array}{r}592 \\
(X) \\
(X) \\
(X) \\
(X) \\
(X) \\
\\
(X)\end{array}$ & $\begin{array}{r}592 \\
(X) \\
(X) \\
(X) \\
(X) \\
(X) \\
(X)\end{array}$ & $\begin{array}{rr}20 & 124 \\
22 & 374 \\
11 & 414 \\
& 64 \\
18 & 631 \\
& 347\end{array}$ & $\begin{array}{rr}20 & 124 \\
3 & 572 \\
6 & 168 \\
& 483 \\
54 & 360 \\
2 & 051\end{array}$ & $\begin{array}{rr}20 & 124 \\
4 & 251 \\
3 & 100 \\
& 50 \\
57 & 737 \\
1 & 446\end{array}$ & $\begin{array}{rr}20 & 124 \\
7 & 673 \\
2 & 225 \\
& 41 \\
42 & 439 \\
1 & 036\end{array}$ & $\begin{array}{rr}20 & 124 \\
10 & 500 \\
6 & 116 \\
& 224 \\
36 & 990 \\
& 584\end{array}$ & $\begin{array}{rr}20 & 124 \\
1 & 013 \\
& 762 \\
& 41 \\
20 & 747 \\
& 884\end{array}$ \\
\hline 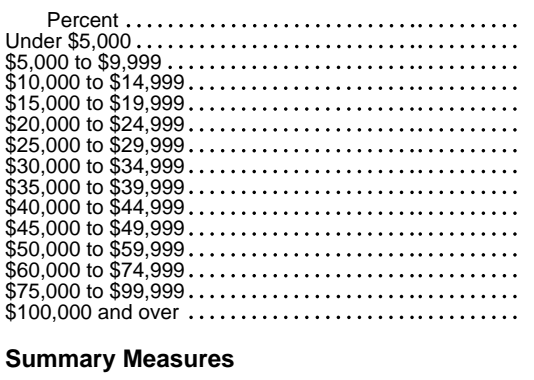 & $\begin{array}{r}100.0 \\
3.3 \\
16.7 \\
16.0 \\
13.0 \\
9.5 \\
8.1 \\
6.1 \\
4.9 \\
3.9 \\
2.8 \\
4.4 \\
4.1 \\
3.3 \\
3.9\end{array}$ & $\begin{array}{r}100.0 \\
3.3 \\
16.7 \\
16.6 \\
13.4 \\
10.2 \\
8.8 \\
6.7 \\
5.4 \\
3.8 \\
2.6 \\
4.3 \\
3.3 \\
2.7 \\
2.1\end{array}$ & $\begin{array}{r}100.0 \\
3.3 \\
16.7 \\
16.6 \\
13.4 \\
10.2 \\
8.8 \\
6.7 \\
5.4 \\
3.8 \\
2.7 \\
4.3 \\
3.3 \\
2.7 \\
2.1\end{array}$ & $\begin{array}{r}100.0 \\
40.7 \\
12.6 \\
8.9 \\
7.0 \\
5.6 \\
4.1 \\
3.3 \\
3.0 \\
2.2 \\
1.8 \\
2.8 \\
2.6 \\
2.5 \\
2.9\end{array}$ & $\begin{array}{r}100.0 \\
40.7 \\
12.6 \\
8.7 \\
6.9 \\
5.6 \\
4.0 \\
3.3 \\
3.0 \\
2.1 \\
1.8 \\
2.7 \\
2.8 \\
2.6 \\
3.1\end{array}$ & $\begin{array}{r}100.0 \\
40.5 \\
12.5 \\
8.6 \\
6.7 \\
5.6 \\
4.0 \\
3.3 \\
3.0 \\
2.2 \\
1.9 \\
2.8 \\
2.8 \\
2.8 \\
3.3\end{array}$ & $\begin{array}{r}100.0 \\
40.9 \\
12.6 \\
8.7 \\
6.9 \\
5.6 \\
4.1 \\
3.4 \\
2.9 \\
2.1 \\
1.9 \\
2.6 \\
2.7 \\
2.6 \\
3.0\end{array}$ & $\begin{array}{r}100.0 \\
40.9 \\
13.2 \\
9.1 \\
7.5 \\
6.1 \\
4.0 \\
3.8 \\
2.7 \\
2.0 \\
1.7 \\
2.6 \\
2.4 \\
2.0 \\
2.0\end{array}$ & $\begin{array}{r}100.0 \\
40.8 \\
13.3 \\
9.1 \\
7.5 \\
6.2 \\
4.1 \\
3.8 \\
2.7 \\
2.0 \\
1.7 \\
2.6 \\
2.4 \\
2.0 \\
2.0\end{array}$ \\
\hline 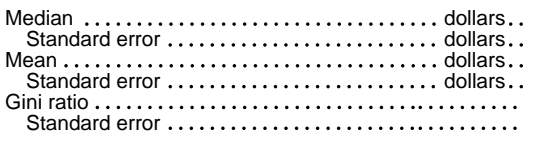 & $\begin{array}{r}20503 \\
236 \\
30 \quad 934 \\
369 \\
.470 \\
.0087\end{array}$ & $\begin{array}{r}19959 \\
204 \\
27 \quad 745 \\
287 \\
.436 \\
.0084\end{array}$ & 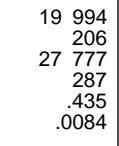 & $\begin{array}{r}8427 \\
226 \\
20173 \\
365 \\
.655 \\
.0088\end{array}$ & $\begin{array}{r}8447 \\
231 \\
21101 \\
408 \\
.664 \\
.0091\end{array}$ & $\begin{array}{r}8552 \\
231 \\
21656 \\
416 \\
.665 \\
.0090\end{array}$ & $\begin{array}{r}8348 \\
226 \\
20 \quad 937 \\
404 \\
.664 \\
.0091\end{array}$ & $\begin{array}{r}8231 \\
207 \\
18 \quad 231 \\
307 \\
.639 \\
.0088\end{array}$ & $\begin{array}{r}8277 \\
207 \\
18264 \\
307 \\
.639 \\
.0087\end{array}$ \\
\hline Quintile Measures & & & & & & & & & \\
\hline 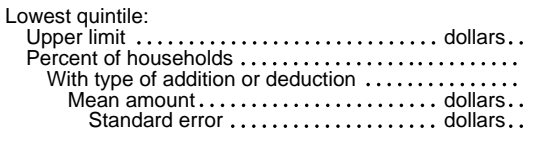 & $14 \begin{array}{r}420 \\
34.0 \\
(X) \\
\\
\\
\\
\\
(X) \\
(X)\end{array}$ & $\begin{array}{r}13408 \\
31.5 \\
(X) \\
(X) \\
(X)\end{array}$ & $\begin{array}{r}13921 \\
32.9 \\
(X) \\
(X) \\
(X)\end{array}$ & $\begin{array}{r}7654 \\
48.5 \\
11213 \\
10 \quad 747 \\
84\end{array}$ & $\begin{array}{r}7679 \\
48.5 \\
514 \\
90 \\
90 \\
128\end{array}$ & $\begin{array}{r}7851 \\
48.7 \\
100 \\
1355 \\
152\end{array}$ & $\begin{array}{r}7410 \\
47.9 \\
1011 \\
290 \\
\\
\\
11\end{array}$ & $\begin{array}{r}7351 \\
47.8 \\
59 \\
\\
\text { (B) } \\
\text { (B) }\end{array}$ & $\begin{array}{r}7756 \\
48.8 \\
293 \\
316 \\
36\end{array}$ \\
\hline 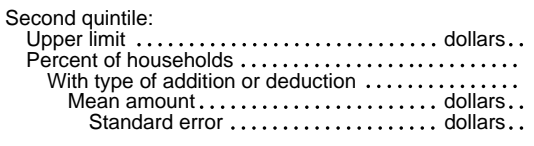 & $\begin{array}{r}26966 \\
28.0 \\
(X) \\
(X) \\
(X)\end{array}$ & $\begin{array}{r}23610 \\
26.4 \\
(X) \\
(X) \\
(X)\end{array}$ & $\begin{array}{r}23831 \\
25.3 \\
(X) \\
(X) \\
(X)\end{array}$ & $\begin{array}{r}22950 \\
24.3 \\
5478 \\
12 \quad 286 \\
126\end{array}$ & $\begin{array}{rr}23086 \\
24.2 \\
838 \\
1196 \\
104\end{array}$ & $\begin{array}{r}24400 \\
24.8 \\
842 \\
1861 \\
59\end{array}$ & $\begin{array}{r}22891 \\
24.5 \\
2255 \\
971 \\
21\end{array}$ & $\begin{array}{r}21450 \\
24.8 \\
4032 \\
854 \\
16\end{array}$ & $\begin{array}{r}21834 \\
24.2 \\
365 \\
870 \\
73\end{array}$ \\
\hline 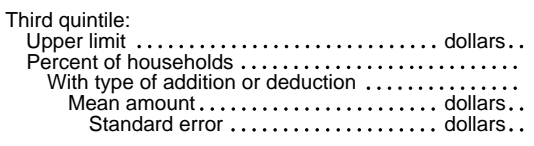 & $\begin{array}{rr}42 & 012 \\
17.4 \\
\\
\\
\\
\\
\\
\\
& (X) \\
& (X)\end{array}$ & $\begin{array}{r}35288 \\
18.2 \\
(X) \\
(X) \\
(X)\end{array}$ & $\begin{array}{rr}35397 \\
18.0 \\
(X) \\
(X) \\
\\
(X)\end{array}$ & $\begin{array}{r}39659 \\
12.2 \\
2649 \\
11657 \\
206\end{array}$ & $\begin{array}{r}39940 \\
12.2 \\
757 \\
2032 \\
173\end{array}$ & $\begin{array}{r}42 \quad 235 \\
11.8 \\
1 \quad 186 \\
2411 \\
\\
\\
55\end{array}$ & $\begin{array}{r}39619 \\
12.5 \\
1757 \\
1 \quad 916 \\
\\
39\end{array}$ & $\begin{array}{rr}36 & 021 \\
12.7 \\
2 \quad 942 \\
2 \quad 893 \\
40\end{array}$ & $\begin{array}{r}36127 \\
12.2 \\
191 \\
880 \\
98\end{array}$ \\
\hline 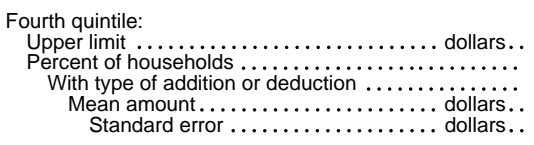 & $\begin{array}{r}65258 \\
11.0 \\
(X) \\
(X) \\
\\
(X)\end{array}$ & $\begin{array}{r}52481 \\
12.7 \\
(X) \\
\\
\\
\\
\\
(X)\end{array}$ & $\begin{array}{rr}52520 \\
12.6 \\
(X) \\
\\
\\
\\
\\
(X) \\
(X)\end{array}$ & $\begin{array}{rr}63 \quad 123 \\
7.7 \\
1522 \\
11547 \\
258\end{array}$ & $\begin{array}{r}63970 \\
7.5 \\
549 \\
3524 \\
266\end{array}$ & $\begin{array}{rr}67 & 767 \\
& 7.4 \\
1 & 010 \\
3 \quad 171 \\
& 80\end{array}$ & $\begin{array}{r}63 \quad 639 \\
7.5 \\
1270 \\
2965 \\
\\
64\end{array}$ & $\begin{array}{rr}56 & 502 \\
& 7.5 \\
1 & 757 \\
6 & 226 \\
& 101\end{array}$ & $\begin{array}{r}56551 \\
7.5 \\
120 \\
1190 \\
140\end{array}$ \\
\hline 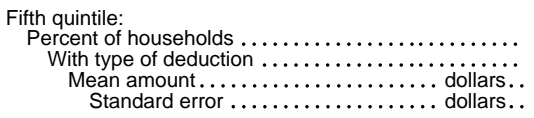 & $\begin{array}{l}9.6 \\
(X) \\
(X) \\
(X)\end{array}$ & $\begin{array}{r}11.2 \\
(X) \\
(X) \\
(X)\end{array}$ & $\begin{array}{r}11.2 \\
(X) \\
(X) \\
(X)\end{array}$ & $\begin{array}{r}7.2 \\
1212 \\
12728 \\
319\end{array}$ & $\begin{array}{rr} & 7.6 \\
913 \\
19 & 171 \\
1 & 713\end{array}$ & $\begin{array}{rr} & 7.3 \\
1 & 113 \\
4 & 863 \\
125\end{array}$ & $\begin{array}{rr} & 7.6 \\
1 & 381 \\
5 & 403 \\
& 134\end{array}$ & $\begin{array}{rr}1 & 7.2 \\
1 & 710 \\
24 & 155 \\
1 & 153\end{array}$ & $\begin{array}{l}7.2 \\
45 \\
(\mathrm{~B}) \\
(\mathrm{B})\end{array}$ \\
\hline
\end{tabular}


VALUATION OF NONCASH BENEFITS

Table 12. Income Distribution Measures by Definition of Income: 1995-Con.

(Numbers in thousands. Households as of March of the following year. For meaning of symbols, see text)

\begin{tabular}{|c|c|c|c|c|c|c|c|c|c|}
\hline \multirow{4}{*}{ Characteristic } & \multicolumn{9}{|c|}{ After taxes-con. } \\
\hline & \multirow[b]{2}{*}{$\begin{array}{r}\text { Definition } 7 \\
\text { less } \\
\text { State } \\
\text { income } \\
\text { taxes }\end{array}$} & \multirow{2}{*}{$\begin{array}{r}\text { Definition } 8 \\
\text { plus } \\
\text { nonmeans- } \\
\text { tested } \\
\text { government } \\
\text { cash } \\
\text { transfers }\end{array}$} & \multirow[b]{2}{*}{$\begin{array}{r}\text { Definition } 9 \\
\text { plus } \\
\text { medicare }\end{array}$} & \multirow[b]{2}{*}{$\begin{array}{r}\text { Definition } 10 \\
\text { plus } \\
\text { regular-price } \\
\text { school } \\
\text { lunches }\end{array}$} & \multirow{2}{*}{$\begin{array}{r}\text { Definition } 11 \\
\text { plus } \\
\text { means-tested } \\
\text { government } \\
\text { cash } \\
\text { transfers }\end{array}$} & \multirow[b]{2}{*}{$\begin{array}{r}\text { Definition } 12 \\
\text { plus } \\
\text { medicaid }\end{array}$} & \multicolumn{2}{|c|}{$\begin{array}{l}\text { Definition } 13 \text { plus other } \\
\text { means-tested government- }\end{array}$} & \multirow{2}{*}{$\begin{array}{r}\text { Definition } 14 \\
\text { plus } \\
\text { net } \\
\text { imputed } \\
\text { return } \\
\text { on equity } \\
\text { in own } \\
\text { home }\end{array}$} \\
\hline & & & & & & & $\begin{array}{l}\text { Noncash } \\
\text { transfers }\end{array}$ & $\begin{array}{r}\text { Noncash } \\
\text { transfers } \\
\text { less medical } \\
\text { programs }\end{array}$ & \\
\hline & 8 & 9 & 10 & 11 & 12 & 13 & 14 & $14 \mathrm{a}$ & 15 \\
\hline \multicolumn{10}{|l|}{$\begin{array}{l}\text { HOUSEHOLDS WITH MEMBERS } 65 \\
\text { YEARS OLD AND OVER }\end{array}$} \\
\hline \multicolumn{10}{|l|}{ Recipiency Status } \\
\hline 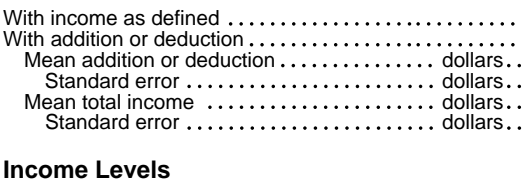 & $\begin{array}{rr}20 & 126 \\
10 & 540 \\
1 & 559 \\
& 50 \\
30 & 749 \\
& 507\end{array}$ & $\begin{array}{rr}23 & 426 \\
22 & 030 \\
11 & 268 \\
& 64 \\
27 & 582 \\
& 286\end{array}$ & $\begin{array}{rr}23 & 501 \\
20 & 707 \\
5 & 063 \\
& 27 \\
34 & 904 \\
& 313\end{array}$ & $\begin{array}{rr}23 & 504 \\
& 459 \\
& 79 \\
& 2 \\
67 & 312 \\
3 \quad 685\end{array}$ & $\begin{array}{rr}23 & 596 \\
1 & 838 \\
3 & 894 \\
& 133 \\
22 & 190 \\
& 824\end{array}$ & $\begin{array}{rr}23 & 596 \\
2 & 354 \\
2 & 140 \\
& 62 \\
32 & 571 \\
& 913\end{array}$ & $\begin{array}{rr}23 & 626 \\
2 & 617 \\
1 & 491 \\
& 34 \\
18 \quad 819 \\
& 553\end{array}$ & $\begin{array}{rr}23 & 626 \\
20 & 748 \\
5 & 296 \\
& 29 \\
14 & 762 \\
409\end{array}$ & $\begin{array}{rr}23 & 701 \\
18 & 737 \\
4 & 636 \\
& 58 \\
40 \quad 487 \\
& 376\end{array}$ \\
\hline 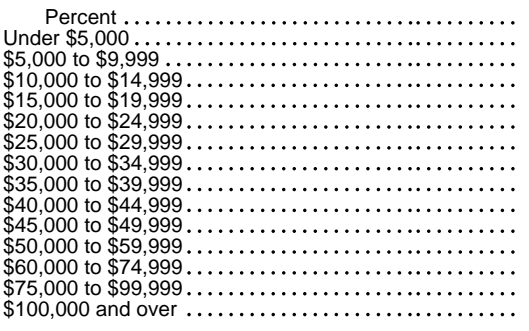 & $\begin{array}{r}100.0 \\
40.9 \\
13.4 \\
9.3 \\
7.6 \\
6.2 \\
4.4 \\
3.6 \\
2.7 \\
1.8 \\
1.6 \\
2.7 \\
2.2 \\
1.8 \\
1.8\end{array}$ & $\begin{array}{r}100.0 \\
5.3 \\
15.5 \\
16.3 \\
13.2 \\
9.7 \\
8.6 \\
6.5 \\
5.2 \\
4.1 \\
2.6 \\
4.3 \\
3.5 \\
3.0 \\
2.3\end{array}$ & $\begin{array}{r}100.0 \\
5.0 \\
11.1 \\
10.0 \\
12.2 \\
10.6 \\
9.0 \\
8.6 \\
7.2 \\
5.3 \\
4.2 \\
5.5 \\
4.8 \\
3.7 \\
2.7\end{array}$ & $\begin{array}{r}100.0 \\
5.0 \\
11.1 \\
10.0 \\
12.2 \\
10.6 \\
9.0 \\
8.6 \\
7.2 \\
5.3 \\
4.2 \\
5.5 \\
4.8 \\
3.7 \\
2.7\end{array}$ & $\begin{array}{r}100.0 \\
3.3 \\
11.9 \\
10.2 \\
12.4 \\
10.6 \\
9.1 \\
8.8 \\
7.4 \\
5.3 \\
4.2 \\
5.6 \\
4.8 \\
3.7 \\
2.7\end{array}$ & $\begin{array}{r}100.0 \\
3.3 \\
11.7 \\
10.2 \\
12.3 \\
10.5 \\
9.2 \\
8.6 \\
7.5 \\
5.5 \\
4.2 \\
5.6 \\
4.9 \\
3.7 \\
2.8\end{array}$ & $\begin{array}{r}100.0 \\
2.9 \\
10.9 \\
10.7 \\
12.9 \\
10.5 \\
9.2 \\
8.6 \\
7.5 \\
5.5 \\
4.3 \\
5.6 \\
4.9 \\
3.7 \\
2.8\end{array}$ & $\begin{array}{r}100.0 \\
2.9 \\
15.4 \\
17.9 \\
13.5 \\
9.9 \\
8.7 \\
6.6 \\
5.3 \\
4.1 \\
2.7 \\
4.4 \\
3.5 \\
3.0 \\
2.3\end{array}$ & $\begin{array}{r}100.0 \\
1.8 \\
8.1 \\
10.1 \\
11.1 \\
10.5 \\
9.0 \\
8.2 \\
7.9 \\
6.8 \\
5.6 \\
6.7 \\
6.0 \\
4.6 \\
3.5\end{array}$ \\
\hline \multicolumn{10}{|l|}{ Summary Measures } \\
\hline 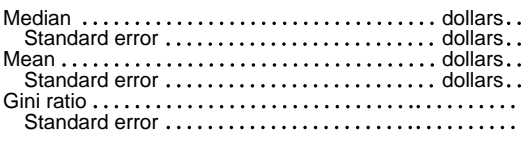 & $\begin{array}{r}8214 \\
203 \\
17571 \\
288 \\
.633 \\
.0086\end{array}$ & $\begin{array}{r}19897 \\
205 \\
28 \quad 031 \\
295 \\
.448 \\
.0084\end{array}$ & $\begin{array}{r}2556 \\
262 \\
32448 \\
305 \\
.420 \\
.0080\end{array}$ & $\begin{array}{r}25556 \\
262 \\
32450 \\
305 \\
.420 \\
.0080\end{array}$ & $\begin{array}{r}25828 \\
258 \\
32752 \\
304 \\
.414 \\
.0080\end{array}$ & $\begin{array}{r}26 \\
035 \\
251 \\
32964 \\
305 \\
.413 \\
.0080\end{array}$ & $\begin{array}{r}26106 \\
251 \\
33128 \\
304 \\
.409 \\
.0080\end{array}$ & $\begin{array}{r}20205 \\
232 \\
28498 \\
294 \\
.435 \\
.0084\end{array}$ & $\begin{array}{r}29611 \\
276 \\
36789 \\
319 \\
.393 \\
.0078\end{array}$ \\
\hline \multicolumn{10}{|l|}{ Quintile Measures } \\
\hline Lowest quintile: & & & & & & & & & \\
\hline 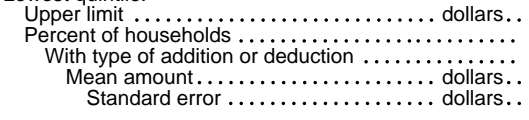 & $\begin{array}{r}7700 \\
48.8 \\
1324 \\
80 \\
3\end{array}$ & $\begin{array}{r}13785 \\
33.2 \\
7 \quad 197 \\
7 \quad 656 \\
49\end{array}$ & $\begin{array}{r}15382 \\
27.0 \\
4012 \\
2005 \\
28\end{array}$ & $\begin{array}{r}15384 \\
27.0 \\
34 \\
\text { (B) } \\
\text { (B) }\end{array}$ & $\begin{array}{rr}15 & 855 \\
27.5 \\
1 & 005 \\
3 & 012 \\
& 115\end{array}$ & $\begin{array}{r}16219 \\
27.9 \\
788 \\
689 \\
29\end{array}$ & $\begin{array}{r}16758 \\
28.8 \\
1645 \\
1622 \\
40\end{array}$ & $\begin{array}{r}14816 \\
35.4 \\
6019 \\
2 \quad 927 \\
30\end{array}$ & $\begin{array}{r}17933 \\
26.4 \\
3633 \\
2392 \\
86\end{array}$ \\
\hline 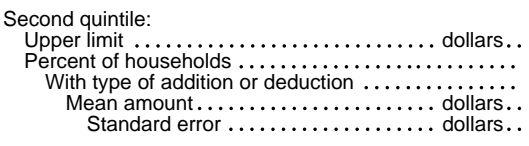 & $\begin{array}{r}21354 \\
24.2 \\
3964 \\
336 \\
7\end{array}$ & $\begin{array}{rr}24957 \\
26.6 \\
6 \quad 051 \\
11896 \\
84\end{array}$ & $\begin{array}{r}26564 \\
24.7 \\
5718 \\
4637 \\
27\end{array}$ & $\begin{array}{r}26570 \\
24.7 \\
28 \\
\text { (B) } \\
\text { (B) }\end{array}$ & $\begin{array}{r}26 \quad 837 \\
24.3 \\
314 \\
4254 \\
311\end{array}$ & $\begin{array}{r}27195 \\
24.2 \\
516 \\
1955 \\
57\end{array}$ & $\begin{array}{r}27429 \\
23.8 \\
496 \\
1223 \\
71\end{array}$ & $\begin{array}{r}25434 \\
24.8 \\
5 \quad 736 \\
5927 \\
45\end{array}$ & $\begin{array}{r}29127 \\
23.0 \\
4 \quad 252 \\
3483 \\
68\end{array}$ \\
\hline 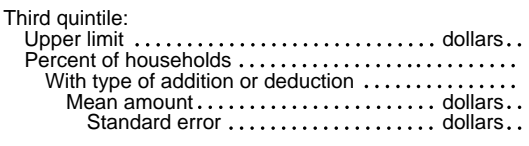 & $\begin{array}{rr}35 & 008 \\
12.4 \\
2 & 351 \\
1 & 105 \\
& 23\end{array}$ & $\begin{array}{r}37682 \\
18.1 \\
4 \quad 058 \\
12964 \\
131\end{array}$ & $\begin{array}{r}38937 \\
20.8 \\
4 \quad 772 \\
6 \quad 325 \\
51\end{array}$ & $\begin{array}{r}38950 \\
20.8 \\
53 \\
\text { (B) } \\
\text { (B) }\end{array}$ & $\begin{array}{r}39096 \\
20.8 \\
245 \\
5794 \\
590\end{array}$ & $\begin{array}{r}39410 \\
20.5 \\
400 \\
2844 \\
114\end{array}$ & $\begin{array}{r}39537 \\
20.1 \\
236 \\
1375 \\
145\end{array}$ & $\begin{array}{rr}37 & 948 \\
17.8 \\
4087 \\
6517 \\
& 62\end{array}$ & $\begin{array}{r}41760 \\
20.1 \\
4206 \\
4389 \\
80\end{array}$ \\
\hline 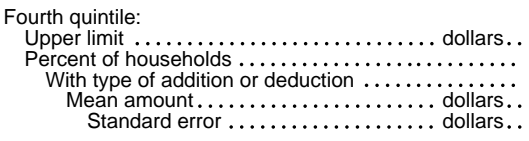 & $\begin{array}{rr}54 & 274 \\
& 7.4 \\
1 & 446 \\
2 & 068 \\
& 46\end{array}$ & $\begin{array}{rr}56093 \\
12.0 \\
2618 \\
14116 \\
230\end{array}$ & $\begin{array}{rr}56986 \\
15.0 \\
3532 \\
6517 \\
\\
66\end{array}$ & $\begin{array}{r}57002 \\
15.0 \\
118 \\
76 \\
4\end{array}$ & $\begin{array}{r}57 \quad 110 \\
14.9 \\
134 \\
5 \quad 011 \\
498\end{array}$ & $\begin{array}{r}57330 \\
14.9 \\
325 \\
3660 \\
212\end{array}$ & $\begin{array}{r}57363 \\
14.8 \\
157 \\
1261 \\
151\end{array}$ & $\begin{array}{rr}56 \quad 239 \\
11.8 \\
2662 \\
6 \quad 464 \\
& 83\end{array}$ & $\begin{array}{r}60300 \\
16.6 \\
3561 \\
5447 \\
\\
120\end{array}$ \\
\hline 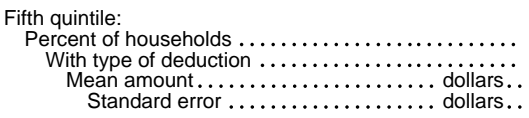 & $\begin{array}{rr}1 & 7.2 \\
1 & 456 \\
6 & 459 \\
& 287\end{array}$ & $\begin{array}{r}10.2 \\
2106 \\
14993 \\
379\end{array}$ & $\begin{array}{rr}12.5 \\
2 & 772 \\
6 & 397 \\
& 75\end{array}$ & $\begin{array}{r}12.5 \\
226 \\
83 \\
4\end{array}$ & $\begin{array}{r}12.5 \\
139 \\
5021 \\
603\end{array}$ & $\begin{array}{r}12.6 \\
325 \\
3565 \\
238\end{array}$ & $\begin{array}{r}12.6 \\
82 \\
1276 \\
242\end{array}$ & $\begin{array}{rr} & 10.2 \\
2 & 243 \\
6 & 426 \\
& 92\end{array}$ & $\begin{array}{rr} & 13.9 \\
3 & 085 \\
8 & 267 \\
239\end{array}$ \\
\hline
\end{tabular}


Weinberg, Daniel H. 1996. "Changing the Way the U.S. Measures Income and Poverty." Prepared for the Canberra Group on Income Statistics, December.

* Paper presented at IASSIST/IFDO ‘97, Odense, Denmark, May 6-9,1997. Daniel H. Weinberg Chief, Housing and Household Economic Statistics Division and Charles T. Nelson Assistant Division Chief for Economic Characteristics Housing and Household Economic Statistics Division U.S. Bureau of the Census Washington, DC 20233-8500 USA May 1997 Phone: (301) 763-8550

Facsimile: (301) 763-8412, E-mail:

Daniel.H.Weinberg@ccmail.census.gov,

Charles.T.Nelson@ccmail.census.gov

${ }^{1}$ This paper is largely based on Weinberg (1996) and Garner et al. (1997).

${ }^{2}$ The history of income questions asked on the Current Population Survey is from Welniak (1990).

${ }^{3}$ The fungible approach for valuing medical coverage assigns income to the extent that having the insurance would free up resources that would have been spent on medical care. The estimated fungible value depends on family income, the cost of food and housing needs, and the market value of the medical benefits. If family income is not sufficient to cover the family's basic food and housing requirements, the fungible value methodology treats Medicare and Medicaid as having no income value. If family income exceeds the cost of food and housing requirements, the fungible value of Medicare and Medicaid is equal to the amount which exceeds the value assigned for food and housing requirements (up to the amount of the market value of an equivalent insurance policy - the total cost divided by the number of participants in each risk class).

${ }^{4}$ These tables also include three additional variants (denoted 1a, 1b, and 14a).

${ }^{5}$ See Fisher (1992) for more historical detail on the development of the poverty thresholds.

${ }^{6}$ Also critical to the definition of poverty is whether to use an absolute or relative measure. A relative measure sets the poverty standard at a fixed fraction, say 50 percent, of some measure of the population's well-being such as median family income. Thus, under a relative poverty measure, only if the incomes for the families at the bottom of the income distribution improve relative to the rest of the distribution would poverty decline. The alternate method of measuring poverty and the one currently in use in the U.S., at least in theory, is more or less an absolute measure. When constructing an absolute measure, one attempts to measure the minimal consumption levels of as many goods as possible. The cost of that consumption bundle is then increased to account for necessary goods not included by use of a "multiplier." Orshansky measured only the cost of a minimally adequate diet. Other proposals have suggested adding shelter, clothing, and medical care to the list. We restrict the discussion here to absolute measures; most observers expect the U.S. poverty concept to retain this feature.

${ }^{7}$ Data are from the Compensation and Working Conditions Branch, U.S. Bureau of Labor Statistics. The 1966 percentage is not strictly comparable to the 1996 figure.

${ }^{8}$ Exceptions are wages and salaries (we suspect that respondents sometimes report net instead of gross earnings) and workers' compensation (payments for injuries on the job.) There are early indications that changes to the SIPP questionnaire in 1996 have ameliorated these problems.

${ }^{9}$ A National Academy of Sciences panel on the future of the SIPP recommended moving toward the use of the SIPP for official income and poverty measurement (Citro and Kalton, 1993).

${ }^{10}$ A full review of budget-based approaches is in Watts (1993).

${ }^{11}$ There is also an issue about whether to use the official CPI or an experimental CPI created to correct for inaccurate measurement of housing costs in the official CPI prior to 1983 . The next CPI market basket revision is scheduled for 1998.

${ }^{12}$ This section drawn from Appendix A of U.S. Bureau of the Census, 1996a.

${ }^{13}$ In general, inventory changes are considered in determining net income from nonfarm self-employment; replies based on income tax returns or other official records do reflect inventory changes. However, when values of inventory changes are not reported, net income figures exclusive of inventory changes are accepted. The value of saleable merchandise consumed by the proprietors of retail stores is not included as part of net income.

${ }^{14}$ In determining farm self-employment incomes, inventory changes are usually considered in determining net income only when they were accounted for in replies based on income tax returns or other official records which reflect inventory changes; otherwise, inventory changes are not taken into account.

${ }^{15}$ Child support paid and other inter-household transfers should theoretically be subtracted from income to avoid double counting, but the data necessary to do so are not collected. 